\title{
Estrogenic regulation of social behavior and sexually dimorphic brain formation
}

\section{Article}

\section{Accepted Version}

Creative Commons: Attribution-Noncommercial-No Derivative Works 4.0

Ogawa, S., Tsukahara, S., Choleris, E. and Vasudevan, N. (2020) Estrogenic regulation of social behavior and sexually dimorphic brain formation. Neuroscience and Biobehavioral Reviews, 110. pp. 46-59. ISSN 0149-7634 doi:

https://doi.org/10.1016/j.neubiorev.2018.10.012 Available at https://centaur.reading.ac.uk/80719/

It is advisable to refer to the publisher's version if you intend to cite from the work. See Guidance on citing.

To link to this article DOI: http://dx.doi.org/10.1016/j.neubiorev.2018.10.012

Publisher: Elsevier

All outputs in CentAUR are protected by Intellectual Property Rights law, including copyright law. Copyright and IPR is retained by the creators or other copyright holders. Terms and conditions for use of this material are defined in the End User Agreement.

\section{www.reading.ac.uk/centaur}

\section{CentAUR}

Central Archive at the University of Reading 
Reading's research outputs online 


\section{Accepted Manuscript}

Title: Estrogenic Regulation of Social Behavior and Sexually Dimorphic Brain Formation

Authors: Sonoko Ogawa, Shinji Tsukahara, Elena Choleris, Nandini Vasudevan

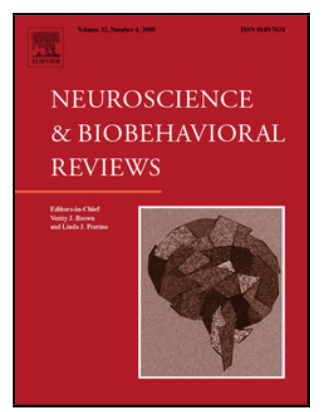

PII:

S0149-7634(18)30277-X

DOI: https://doi.org/10.1016/j.neubiorev.2018.10.012

Reference: NBR 3246

To appear in:

Received date: $\quad 16-4-2018$

Revised date: $\quad 17-10-2018$

Accepted date: $\quad$ 22-10-2018

Please cite this article as: Ogawa S, Tsukahara S, Choleris E, Vasudevan N, Estrogenic Regulation of Social Behavior and Sexually Dimorphic Brain Formation, Neuroscience and Biobehavioral Reviews (2018), https://doi.org/10.1016/j.neubiorev.2018.10.012

This is a PDF file of an unedited manuscript that has been accepted for publication. As a service to our customers we are providing this early version of the manuscript. The manuscript will undergo copyediting, typesetting, and review of the resulting proof before it is published in its final form. Please note that during the production process errors may be discovered which could affect the content, and all legal disclaimers that apply to the journal pertain. 


\section{IBNS special issue of Neuroscience and Biobehavioral Reviews}

\section{Estrogenic Regulation of Social Behavior and Sexually Dimorphic Brain Formation}

Sonoko Ogawa ${ }^{1^{*}}$, Shinji Tsukahara ${ }^{2^{*}}$, Elena Choleris ${ }^{3^{*}}$ and Nandini Vasudevan ${ }^{4^{*}}$

1: Laboratory of Behavioral Neuroendocrinology, University of Tsukuba, 1-1-1 Tennodai, Tsukuba, 3058577, Japan.

2: Division of Life Science, Graduate School of Science and Engineering, Saitama University, 255 ShimoOkubo, Sakura-ku, Saitama City, Saitama 338-8570, Japan.

3: Department of Psychology and Neuroscience Program, University of Guelph, Guelph, ON, N1G 2W1, Canada

4: School of Biological Sciences, University of Reading, WhiteKnights Campus, Reading, United Kingdom RG6 6AS.

*: All four authors equally contributed to this article. They also dedicate this article to their long-term collaborator and friend Dr. Sergei Musatov, who was tragically killed in May, 27, 2015 in New York City.

Corresponding author:

Sonoko Ogawa, Ph.D.

Laboratory of Behavioral Neuroendocrinology, University of Tsukuba,

Research Building D-409,

1-1-1 Tennodai, Tsukuba, Ibaraki 305-8577, Japan,

Tel/fax: +81298532966

e-mail: ogawa@kansei.tsukuba.ac.jp

Total number of pages: 30

Total number of figures: 3

Total number of words in text (excluding title page and references): 10764

\section{Highlights}

- Gonadal hormones affect the morphology of sexually dimorphic nuclei (SDNs) of the brain.

- The principal nucleus of the bed nucleus of the stria terminals (BNSTp) is a male-dominant SDN.

- The BNSTp contains not only a male-dominant subregion but also a female-dominant subregion. 
- ER $\alpha$ and ER $\beta$ may have opposing effects on the estrogenic regulation of sex-typical social behaviors.

- Both genomic and non-genomic signaling by estrogens regulate social recognition and learning.

- Spinogenesis may be a critical mechanism by which estrogens, via ERs, regulates social behaviors.

\section{Abstract}

It has long been known that the estrogen, $17 \beta$-estradiol (17 $\beta-E)$, plays a central role for female reproductive physiology and behavior. Numerous studies have established the neurochemical and molecular basis of estrogenic induction of female sexual behavior, i.e., lordosis, in animal models. In addition, $17 \beta$-E also regulates male-type sexual and aggressive behavior. In males, testosterone secreted from the testes is irreversibly aromatized to $17 \beta-E$ in the brain. We discuss the contribution of two nuclear receptor isoforms, estrogen receptor (ER) $\alpha$ and $E R \beta$ to the estrogenic regulation of sexually dimorphic brain formation and sex-typical expression of these social behaviors. Furthermore, $17 \beta-\mathrm{E}$ is a key player for social behaviors such as social investigation, preference, recognition and memory as well as anxiety-related behaviors in social contexts. Recent studies also demonstrated that not only nuclear receptor-mediated genomic signaling but also membrane receptor-mediated non-genomic actions of $17 \beta-E$ may underlie the regulation of these behaviors. Finally, we will discuss how rapidly developing research tools and ideas allow us to investigate estrogenic action by emphasizing behavioral neural networks.

Keywords: $17 \beta$-estradiol; genomic action; membrane-mediated non-genomic action; estrogen receptor $\alpha$; estrogen receptor $\beta$; hypothalamus; hippocampus; sexual behavior; aggressive behavior; parental behavior; sexually dimorphic nuclei; testosterone; dendritic spines; social behavioral networks; social recognition; social learning 


\section{Introduction}

\subsection{Genomic vs. non-genomic action of $17 \beta$-estradiol}

The estrogen, $17 \beta-\mathrm{E}$ is a steroid hormone that signals via both non-genomic and genomic pathways in the central nervous system (CNS) in order to drive behavior. Considering that non-genomic signaling is often defined "in opposition" to genomic signaling, it is important to first define genomic signaling. $17 \beta-E$ is a ligand for the nuclear receptors, $E R \alpha$ and $E R \beta$ which act as ligand-activated transcription factors. As transcription factors, they bind to estrogen response elements (ERE), a cognate enhancer element and regulate transcription from target genes. This "genomic" slow mode of signaling requires intracellular receptors and is thought to occur in all cells that express ER $\alpha$ or ER $\beta$ (Mangelsdorf et al., 1995; Nilsson et al., 2001). On the other hand, non-genomic signaling is fast signaling mostly initiated at the plasma membrane by a putative membrane estrogen receptor ( $m E R$ ) that binds $17 \beta-E$ (Vasudevan and Pfaff, 2007). This results in the activation of kinases (Qiu et al., 2003) and calcium flux (Temple and Wray, 2005) within cells (Figure 1). Non-genomic signaling has been shown to be important in cardiovascular physiology (Feldman and Limbird, 2017) and in pathologies such as breast cancer where non-genomic signaling is an important pathway by which cancerous cells acquire resistance to endocrine therapy (Anbalagan et al., 2012; Le Romancer et al., 2010). In the last decade or so, the coupling of these pathways i.e. non-genomic signaling to genomic transcription has led to the idea of an integrated signaling pathway that starts at the membrane and culminates in the nucleus (Figure 1) (Micevych and Dewing, 2011) (Vasudevan et al., 2005).

\subsection{The distribution of the intracellular $E R \alpha$ and $E R \beta$ in the brain}

$17 \beta-E$ binds to intracellular ER $\alpha$ and ER $\beta$ with similar affinity. Though the distribution of the two receptor isoforms partly overlaps, some brain areas that are known to be part of the social behavioral network (Nelson and Trainor, 2007; Newman, 1999) express either ER $\alpha$ or ER $\beta$ more strongly (Mitra et al., 2003; Nomura et al., 2003; Shughrue et al., 1997). For instance, ER $\alpha$, but not ER $\beta$, is highly expressed in the ventromedial nucleus of the hypothalamus $(\mathrm{VMH})$, which plays a central role for the induction of female sexual behavior via genomic action of $17 \beta-\mathrm{E}$ as we discuss extensively in Section 3 . On the other hand, ER $\beta$ is more abundant than ER $\alpha$ in the brain areas such as the paraventricular nucleus of the hypothalamus (PVN) and the dorsal raphe nucleus of the midbrain (DRN). A number of hypothalamic and limbic brain regions such as the medial preoptic area (mPOA), the medial amygdala (MeA), the bed 
nucleus stria terminalis (BNST) and the lateral septum (LS) are known to express both ER $\alpha$ and ER . Although some studies have reported that there are neurons which express both ER $\alpha$ and ER (Greco et al., 2001; Shughrue et al., 1998) in rat brains, it is largely unknown how much ER $\alpha$ and ER $\beta$ are coexpressed at the level of an individual cell, partly due to a lack of effective antibody for ER $\beta$ detection (Snyder et al., 2010). It is expected that the recently developed transgenic mice tagged for ER $\beta$ (Milner et al., 2010; Oyola et al., 2017; Sagoshi et al., 2018; Zuloaga et al., 2014) will provide more detailed information on this matter and contribute to a better understanding of the respective roles of ER $\alpha$ and $E R \beta$ in the estrogenic regulation of social behavior.

\subsection{The membrane $E R(m E R)$ in the hypothalamus and hippocampus}

Unlike classical genomic signaling that is initiated by the intracellular $E R \alpha$ or $E R \beta$, non-classical signaling is generally initiated by a mER but the identity of a unique mER is still controversial. ER $\alpha$, including variants of ER $\alpha$ that lack some portions of the $\mathrm{N}$-terminal domain has been shown at the membrane in hypothalamic cell lines (Dominguez et al., 2013) and in neurons (Dominguez and Micevych, 2010) though the mechanism of attachment to the plasma membrane for nuclear receptors has been disputed (Rainville et al., 2015). In the hippocampus, ER $\alpha$ and ER $\beta$ are linked to mGluR2/3 via the adaptor, caveolin 3, leading to $G \alpha_{i / o}$ signaling within cells. ER $\alpha$ can also be linked to mGluR1 via caveolin 1 (Boulware et al., 2007), resulting in $G_{\alpha q}$ signaling within cells. To our knowledge, ER $\beta$ signaling via glutamate receptors in the hypothalamus remains unexplored. Hence, ER $\alpha$ or ER $\beta$ serve not only as an intracellular receptor mediating classical genomic signaling but may also play a dual role as a receptor at the plasma membrane to mediate rapid non-genomic signaling. For a discussion on the various proteins that may function as mERs, the reader is referred to (Rainville et al., 2015)

A novel G-protein coupled receptor (GPCR) called GPR30 or GPER1 was shown to bind 17 $\beta$-E at high affinity and activate $\mathrm{G} \alpha_{s}$-coupled signaling in breast cancer cells in 2005 (Thomas et al., 2005). GPR30 is widely distributed in the CNS and is present in the amygdala, hypothalamus and hippocampus (Brailoiu et al., 2007). 17 $\beta$-E binding to GPER1 can activate protein kinase A (PKA) and phosphoinositide3-kinase (PI3K) pathways, as well as increase ERK activity via the activation of epidermal growth factor receptor (EGFR) (Prossnitz and Barton, 2009; Prossnitz and Maggiolini, 2009). In addition, GPER1 activation induces calcium increases which appear to be ryanodine receptor dependent in breast cancer cells (Ariazi et al., 2010). In the brain, GPER1 is implicated in reproductive behavior, social cognition, 
spatial memory, and neuroprotection (Alexander et al., 2016; Hadjimarkou and Vasudevan, 2018), suggesting that rapid, non-genomic signaling influences these behaviors.

This review is based on a symposium presented by the authors at the 2018 annual conference of the International Behavioral Neuroscience Society. The basis of the sex-specific social behaviors described in this review is the development of a sexually dimorphic brain, which is itself regulated by local production of steroid hormones during critical periods of development (Section 2). Our objectives in Sections 3 and 4 are to focus on both genomic and non-genomic signaling pathways that underlie $17 \beta$-E-mediated social behaviors such as sex and aggression as well as underlying state anxiety with particular emphasis on the contribution of the various receptors.

\section{Role of sex steroids in the sexually dimorphic formation of brain structures underlying the control of social behavior}

In the sexually differentiated brain, there are sex differences in the tissue structures. Nuclei exhibiting morphological sex differences are called sexually dimorphic nuclei, in which sex difference in the volume and the morphology and number of neurons and glial cells, synaptic number, etc. are seen. Sexually dimorphic nuclei are considered the structural basis for generating sex differences in brain functions. Estrogens not only modulate the neural control of social behavior but also play an essential role in the sexually dimorphic formation of brain structures to construct neural circuits that control sexspecific physiological phenomenon, including social behavior. Though sex is also genetically determined, in this section, we focus specifically on the role of sex steroids, $17 \beta-E$ and testicular testosterone which not only acts directly but also acts as $17 \beta$-E after aromatization in the brain, in the formation of sex differences in volume and neuron number of the sexually dimorphic nuclei found in the MPOA and BNST that control social behavior. Additionally, a recently identified sexually dimorphic cell group is introduced. The roles of sex steroids in the formation of this sexually dimorphic cell group and a possible role of this cell group in social behavior will be discussed.

\subsection{Contribution of sex steroids to the sexually dimorphic formation of brain structures}

It has long been known that testosterone secreted from developing testes plays an important role in brain sexual differentiation. In 1959, Phoenix and colleagues reported on the sexual behavior of guinea pigs that were born from mothers injected with testosterone during pregnancy (Phoenix et al., 1959). According to their report, females exposed to exogenous testosterone in the embryonic period had 
greatly reduced performance to display female sexual behavior in adulthood. In contrast, these females displayed male sexual behavior when they were treated with exogenous testosterone in adulthood. Male littermates exposed to exogenous testosterone showed male sexual behavior in adulthood as normal males that secreted testosterone from the testes during the embryonic period displayed male sexual behavior. These results demonstrate that the action of testicular testosterone in the embryonic period causes masculinization and defeminization of sexual behavior, and the effects of testosterone persist into adulthood. The concept proposed by Phoenix and colleagues has been supported by many studies. Additionally, in rodents, it has been revealed that $17 \beta-E$, which is locally synthesized in the brain from testicular testosterone by aromatase in the perinatal period, affects the brain to masculinize and defeminize sexual behavioral patterns (MacLusky et al., 1979; MacLusky and Naftolin, 1981; McEwen et al., 1977). Injection of an anti-androgen drug or an aromatase inhibitor into pregnant rats enhances the activity of female sexual behavior in offspring in both sexes in adulthood (Clemens and Gladue, 1978; Gladue and Clemens, 1978, 1982). In contrast, neonatal testosterone treatment decreases the activity of female sexual behavior in rats of both sexes (Gladue and Clemens, 1982). This effect of testosterone can be mimicked by estrogens, because the activity of female sexual behavior in female rats and neonatally castrated male rats is reduced by $\beta$-estradiol-3-benzoate $(E B)$ injection in the postnatal period (Brown-Grant, 1975; Feder and Whalen, 1965; Whalen and Nadler, 1963). Thus, the perinatal period is the critical period for the sexual differentiation of the brain in rodents. However, currently it is considered that the perinatal period is not the sole stage but the initial stage of sex steroid-dependent sexual differentiation of the brain in rodents (Juraska et al., 2013; Schulz et al., 2009). In the classic view of brain sexual differentiation, $17 \beta-E$ affects the brain during the perinatal period to masculinize and defeminize the brain. However, in addition to this action, $17 \beta$-E plays a role in feminizing the brain during the peripubertal period. Female aromatase knockout mice showed low levels of the activity of lordosis, a female sexual behavior, even after being treated with $17 \beta$-E and progesterone at adulthood (Bakker et al., 2002). The decreased lordotic activity in female aromatase knockout mice is recovered by injection of EB in the prepubertal period (Brock et al., 2011). Thus, the neural system involved in the regulation of female sexual behavior is defeminized in males by $17 \beta$-E originating from testicular testosterone during the perinatal period and conversely feminized in females by $17 \beta-E$ that is synthesized from the ovary during the prepubertal period. In addition to the effects of sex steroids, it has been demonstrated that genes on the sex chromosomes directly influence the sexual differentiation of the brain; these mechanisms and models to study them are reviewed in Arnold, 2014; Cox et al., 2014; McCarthy and Arnold, 2011. 
Testosterone secreted from the testes in the perinatal period is a key molecule in the formation of sexually dimorphic nuclei (Figure 2). The sexually dimorphic nucleus of the preoptic area (SDN-POA) and the principal nucleus of the bed nucleus of the stria terminalis (BNSTp) in males are larger in volume and contain greater number of neurons than those in females of rats and mice (del Abril et al., 1987; Forger et al., 2004; Gorski et al., 1978; Gorski et al., 1980; Hines et al., 1992) (Figure 3). The SDN-POA and BNSTp exist in other species (Campi et al., 2013; Moe et al., 2016b), suggesting that these sexually dimorphic nuclei are evolutionally conserved across species. Intriguingly, the magnitude of sex difference in SDN-POA volume appears to be correlated with social organization: this sex difference is more salient in polygamous species than in monogamous species (Campi et al., 2013). The volume and neuron numbers of the SDN-POA and BNSTp in adult females are increased by administration of testosterone during the postnatal period, whereas those in adult males are decreased by neonatal orchidectomy (Chung et al., 2000; Gorski et al., 1978; Guillamon et al., 1988). In contrast, the anteroventral periventricular nucleus (AVPV) is a sexually dimorphic nucleus that is larger in size and has higher cell density in females than in males (Bleier et al., 1982; Sumida et al., 1993) (Figure 3). The volume of the AVPV in female rats is reduced by postnatal treatment with testosterone (Ito et al., 1986). Because the effect of testosterone on sexually dimorphic nuclei can be mimicked by $17 \beta$-E (Hisasue et al., 2010; Patchev et al., 2004), testicular testosterone during the perinatal period is thought to act on sexually dimorphic nuclei after it is converted to $17 \beta-E$ by aromatase.

As mentioned above, testosterone secreted from the testis in the perinatal period is important for brain sex differentiation in rodents. However, this testosterone action is not enough to complete the processes of brain sexual differentiation. Besides perinatal testicular testosterone, gonadal hormones secreted in the peripubertal period have been shown to influence the sexual differentiation of the brain (Juraska et al., 2013; Schulz et al., 2009) (Figure 2). During puberty, gonads become mature, and thereby the secretion of testicular testosterone and ovarian $17 \beta-E$ increases. The brain affected by testicular testosterone in the perinatal period is again affected by testicular testosterone in the pubertal period, so that the brain is masculinized and defeminized. Estrogens secreted from the ovaries during puberty act to feminize and demasculinize the brain. New cells generated during puberty are added to the AVPV, SDN-POA, and MeA, a sexually dimorphic nucleus having larger volume and greater number 
of spines in males (Mizukami et al., 1983; Nishizuka and Arai, 1981a, b), and that the numbers of new cells in the AVPV of female rats and in the SDN-POA and MeA of male rats are greater than those in the opposite sex (Ahmed et al., 2008). This finding indicates that cell generation during puberty significantly contribute to the formation of the sexually dimorphic nuclei. In addition, gonadectomy before puberty inhibits the increase in the number of new cells and the volume of the female AVPV and the male SDNPOA, and new cell numbers of the male MeA (Ahmed et al., 2008). These findings indicate that gonadal hormones during puberty also influence the formation of the sexually dimorphic nuclei.

Although the mechanisms of sex steroid actions on the formation of sexually dimorphic nuclei are not well understood, there are several studies that help to understand the mechanisms, in particular the contribution of the ERs and the AR. The volume and neuron numbers of the BNSTp in male mice are decreased by deletion of the ER $\alpha$ gene and become similar to those in female mice (Tsukahara et al., 2011). In addition, the volume and neuron numbers of the AVPV in ER $\alpha$ knockout male mice become similar to those in female mice compared with wild-type male mice (Kanaya et al., 2014). In contrast, there is no significant effect of lacking the ER $\beta$ gene on the sexually dimorphic formation of the BNSTp and AVPV (Kanaya et al., 2014; Tsukahara et al., 2011). However, there are reports showing that administration of an ERß agonist, as well as an ER $\alpha$ agonist, into postnatal females has a pharmacological effect to increase the number of BNSTp neurons in mice (Hisasue et al., 2010) and decrease the number of AVPV neurons in rats (Patchev et al., 2004). Deletion of the aromatase gene, as well as the ER $\alpha$ gene, induces abnormal formation of the morphology of the BNSTp and AVPV in male mice but not in female mice (Kanaya et al., 2014; Tsukahara et al., 2011). Additionally, formation of male BNSTp is disrupted in rats that exhibit testicular feminization associated with mutation of the androgen receptor (AR) gene (Allieri et al., 2013; Durazzo et al., 2007) and in AR knockout mice (Kanaya et al., 2014), although the AVPV in the male brain develops normally without functional AR (Kanaya et al., 2014; Simerly et al., 1997). Based on these studies with gene knockout mice, it is likely that testicular testosterone promotes organization of the male AVPV through mainly binding to ER $\alpha$ after aromatization. The AVPV of mice expresses the mRNAs of ER $\alpha$ and aromatase during the perinatal period, and it expresses the mRNA of ER $\alpha$ but not aromatase in the peripubertal period (Kanaya et al., 2018; Kanaya et al., 2014), suggesting that the male AVPV is organized by the actions of aromatized testosterone via ER $\alpha$ during the perinatal period. Regarding the BNSTp, the formation of this nucleus in male mice requires not only aromatized testosterone actions via ER $\alpha$ but also the actions of androgens binding to AR. In the BNSTp of mice, the mRNAs of ER $\alpha$ and aromatase were expressed in the perinatal 
and peripubertal periods, and the mRNA of AR was expressed in the postnatal and peripubertal periods (Kanaya et al., 2018; Kanaya et al., 2014).

Sickel and McCarthy reported that the SDN-POA of rats contains neurons expressing calbindinD28K (CALB), a calcium binding protein (Sickel and McCarthy, 2000). The cluster of CALB-D28K neurons in the male SDN-POA is larger than that in the female SDN-POA of rats and mice (Orikasa and Sakuma, 2010; Sickel and McCarthy, 2000). CALB-D28K is therefore used as a marker to identify a sexually dimorphic nucleus that is included in the SDN-POA and was termed the CALB-SDN (Figure 3). Like the SDN-POA, the BNSTp contains many CALB-D28K neurons, and the number of CALB-D28K neurons in the BNSTp is larger in males than in females (Gilmore et al., 2012; Morishita et al., 2017). Hereafter the BNSTp identified by CALB-D28K is termed CALB-BNSTp (Figure 3). Thus, CALB-D28K is useful to determine not only the CALB-SDN but also the CALB-BNSTp, although the physiological roles of CALBD28K in the CALB-SDN and CALB-BNSTp require further investigation. The volume of the CALB-SDN and CALB-BNSTp are increased in adult female mice by postnatal treatment with testosterone propionate and EB, but not dihydrotestosterone, a non-aromatizable testosterone (Morishita et al., 2017; Orikasa and Sakuma, 2010), suggesting that postnatal testicular testosterone is aromatized and then acts via binding to ER for masculinization of the CALB-SDN and CALB-BNSTp.

The mechanisms by which the CALB-SDN and CALB-BNSTp are masculinized after testicular testosterone during the perinatal period acts there are largely unclear. Control of cell number by apoptosis and actions of sex steroids in apoptosis is known to be critical for the formation of sexually dimorphic nuclei (Tsukahara, 2009). However, sex differences in the number of CALB-D28K neurons in the CALB-SDN and CALB-BNSTp are not eliminated by the deletion of proapoptotic Bax gene (Gilmore et al., 2012), suggesting that apoptotic control of cell number contributes less to the formation of CALBSDN and CALB-BNSTp. On the other hand, the formation of sex difference in the number of CALB-D28K neurons may involve the epigenetic control of cell phenotype, because neonatal treatment of a DNA methyltransferase inhibitor increases CALB-D28K neuron number in both sexes (Mosley et al., 2017). Additionally, it was reported that the volume of the BNSTp in male mice and neonatally testosteronetreated female mice is reduced by a histone deacetylase inhibitor (Murray et al., 2009), suggested that a disruption in histone deacetylation induces long-term alterations in gene expression that suppress the masculinizing actions of testosterone in the BNSTp.

In the CALB-SDN and CALB-BNSTp, the sex differences in the volume and numbers of CALB-D28K neurons emerge before puberty (Morishita et al., 2017; Wittmann and McLennan, 2013a, b). The sex 
differences become prominent in adulthood with increasing volume and neuron numbers in male mice and decreasing volume and neuron numbers in female mice, excepting CALB-SDN volume in females (Morishita et al., 2017; Wittmann and McLennan, 2013a, b). In addition to cell generation, cell loss during the pubertal period is also involved in the organization of sexually dimorphic nuclei. The volume and calbinidn-D28K neuron numbers of the CALB-BNSTp and CALB-SDN in adult male mice are decreased by prepubertal orchidectomy, although those in adult female mice are not affected by prepubertal ovariectomy (Morishita et al., 2017). Additionally, in the CALB-BNSTp of prepubertally orchidectomized male mice, it was revealed that the decreased volume and calbinidin-D28K neuron number by prepubertal orchidectomy are recovered by testosterone replacement in the peripubertal period (Kanaya et al., 2018). These findings indicate that testicular hormones in the peripubertal period act in remodeling the brain after it develops with the organizational effect of testicular testosterone during the perinatal period.

\subsection{Morphology, sexual differentiation, and functions of a novel sexual dimorphic cell group}

A number of sexually dimorphic nuclei have been identified in the brains of many species. However, potential still exists to uncover novel sexually dimorphic brain structures. Even if sexually dimorphic nuclei have been identified, the details of the morphological features and physiological functions of the sexually dimorphic nuclei are not well understood. As mentioned in the above section, the BNSTp identified by Nissl staining and the CALB-BNSTp identified by CALB-D28K are sexually dimorphic nuclei that contain more neurons and are larger in volume in male mice than in female mice. When the CALB-BNSTp is compared with the BNSTp, it can be found that the ventral part of the BNSTp does not express CALB-D28K (Morishita et al., 2017). It has been reported that p21 protein (Cdc42/Rac)activated kinase 3 (Pak3) is abundantly expressed in the BNSTp of mice and can be used as another marker for BNSTp (Morishita et al., 2017). According to this study, a ventral part of the BNSTp expresses Pak3 but not CALB-D28K. The ventral part of the BNSTp (hereafter BNSTpv) in female mice was larger in volume than the BNSTpv of male mice, although the volume of BNSTp identified by Pak3 and CALBBNSTp identified by CALB-D28K was larger in males than in females (Morishita et al., 2017). Thus, the BNSTp showing male-dominant morphological sex difference is composed not only of male-dominant sexually dimorphic cell group, CALB-BNSTp, but also of a newly found female-dominant sexually dimorphic cell group, BNSTpv (Figure 3).

Gonadal hormones play an essential role in the sexually dimorphic formation of the BNSTpv as well as other sexually dimorphic nuclei. The volume and neuron numbers of the BNSTpv in male mice 
are increased by neonatal orchidectomy. In contrast, subcutaneous injection of testosterone, $17 \beta-E$, or dihydrotestosterone into postnatal female mice reduce the volume and neuron numbers of the BNSTpv in adulthood (Morishita et al., 2017). These findings suggest that testicular testosterone in the postnatal period acts to defeminize the BNSTpv through binding to AR directly and through binding to ER after aromatization. Furthermore, the sexually dimorphic formation of the BNSTpv appears to be affected by gonadal hormones during puberty. The volume and neuron numbers of the BNSTpv in adult female mice are decreased by prepubertal ovariectomy (Morishita et al., 2017), suggesting that pubertal ovarian hormones affect the BNSTpv so that the BNSTpv are reorganized for feminization. The effects of prepubertal ovariectomy on the BNSTpv may be due to a lack of estrogens during puberty, because treatment with $17 \beta-E$ during puberty can rescue the effects of prepubertal ovariectomy (unpublished data). In male mice, the volume and neuron numbers of the BNSTpv in adulthood are not affected by prepubertal orchidectomy, although neonatal orchidectomy significantly affects the formation of the BNSTpv (Morishita et al., 2017). Taken together, the sexually dimorphic formation of the BNSTpv requires the actions of testicular testosterone in the postnatal period and of ovarian $17 \beta-E$ in the pubertal period.

As mentioned before, the BNSTpv of female mice is larger in volume and contains more neuron numbers compared to the BNSTpv of male mice. Additionally, the BNSTp may exhibit a female-dominant sex difference in ER $\alpha$ expression, because the dorsal hypothalamic area corresponding to the BNSTpv has more cells expressing ER $\alpha$ and shows a higher expression level of ER $\alpha$ in female mice than in male mice (Moe et al., 2016a). Physiological functions of the BNSTpv are largely unknown. However, because of the female-dominant sex differences in neuron numbers and ER $\alpha$ expression, the BNSTpv may be involved in female-typical behaviors that require $17 \beta-E$ binding to ER $\alpha$. In sexually receptive females displaying lordosis, the expression of c-Fos, a neuronal activity maker, increases or decreases in several brain regions regulating the behavior (Coolen et al., 1996; Pfaus et al., 1996). However, c-Fos expression does not change in the BNSTpv of females displaying lordosis (Moe et al., 2016a), suggesting that the BNSTpv of female mice contributes less to sexual behavior. The BNSTpv is a part of the bed nucleus of the stria terminalis (BNST) and is located dorsal to the MPOA. The MPOA and BNST play key roles in maternal behavior (Numan et al., 1988; Tsuneoka et al., 2013). 17 $\beta$-E signaling via ER $\alpha$ is an important component of the pathways that stimulate maternal behavior (Bridges, 2015; Pfaff et al., 2011). Therefore, it was examined whether the BNSTpv in female mice is involved in maternal behavior. The expression of c-Fos in the BNSTpv was analyzed in virgin female mice and primiparous mothers after 
they were exposed to pups in their home cages (Moe et al., 2016a). In this analysis, primiparous mothers exhibited higher performance of maternal behavior than did virgin female mice. In the mPOA and BNST of female mice, exposure to pups and subsequent display of maternal behavior generally increase c-Fos expression (Tsuneoka et al., 2013). However, c-Fos expression in the BNSTpv of primiparous mothers was lower than that of virgin female mice. This suggests that there is a neuronal population, the activity of which decreases with increasing maternal behavior performance. The BNSTpv may contain neurons that play an inhibitory role in maternal behavior, although clarification of the physiological functions of the BNSTpv requires further investigation.

\section{Estrogenic regulation of sex-typical social behavior}

Social behaviors are behaviors that are influenced by and can influence behavior by other members of the same species. In this sense, both sex and aggression are social behaviors that are sexually dimorphic; however, both are typically considered separate from other social behaviors such as social recognition or pair bonding. We discuss the contribution of signaling by estrogens to these behaviors in rodents in this section, followed by a section of estrogenic regulation of social recognition and social learning.

\subsection{Female sexual behavior}

A neural "bioassay" of activational estrogenic action in the adult brain is the $17 \beta$-E-induced classical reproductive behavior, lordosis, in female rodents (Pfaff, 1999). In rats and mice, 17ß-E signaling in the ventromedial hypothalamus (VMH), particularly in the ventrolateral part (vIVMH), is necessary for lordosis behavior (Davis et al., 1979; Pfaff and Sakuma, 1979). The time-dependent transcriptional upregulation of progesterone receptor (PR) in the VMH by $17 \beta-\mathrm{E}$ (Parsons et al., 1982a; Parsons et al., 1982b) is representative of the genomic signaling pathway that is required for lordosis behavior. Knockout mice of $E R \alpha$, during gonadally intact as well as subsequent to priming with $E B$ plus progesterone after ovariectomy, are not sexually receptive at all (Ogawa et al., 1998; Ogawa et al., 1996) (Rissman et al., 1997). It is reported that ERa knockout female mice do not show any proceptive still posture or receptive lordosis posture in response to attempted mounts by sexually active male mice and rather show very strong rejection responses, such as kicking, fleeing, and upright posture (Ogawa et al., 1998). In ER $\alpha$ knockout mice, as expected, PR induction by EB priming was greatly reduced in the vIVMH. These findings in knockout mouse model are consistent with pharmacological studies reporting facilitation of lordosis behavior in female rats by either subcutaneous or intracerebroventricular 
injections of ER $\alpha$ specific agonist, propyl-pyrazole triol (Dominguez-Ordonez et al., 2016; Mazzucco et al., 2008). All these studies do not provide further information about responsible brain site(s) of ER $\alpha$ mediated estrogenic regulation on female sexual behavior. Studies using brain site-specific gene knockdown methods revealed that reduction of the levels of $\mathrm{ER} \alpha$ in the $\mathrm{VMH}$, but not in the adjacent ER $\alpha$-rich arcuate nucleus, by siRNA abolishes both proceptive still posture and lordosis behavior (Musatov et al., 2006). These ER $\alpha$ knockdown mice show very similar behavioral responses (eg., kicking and fleeing, etc.) in response to sexually active male mice as those seen in ER $\alpha$ knockout mice (Musatov et al., 2006). In both cycling and EB-primed ovariectomized mice treated with siRNA for ER $\alpha$ knockdown, PR was not expressed in EGFP, the reporter protein for siRNA transduction, positive cells. Therefore, it is concluded that $17 \beta-\mathrm{E}$ via ER $\alpha$-mediated transcription of the PR in the VMH is a critical genomic signaling pathway for this behavior.

The function of intracellular ER $\beta$ in the estrogenic regulation of lordosis behavior may be very different from that of $E R \alpha$. Unlike $E R \alpha$, only a small number of $E R \beta$ immunopositive cells are found in the limited area of the vIVMH (Mitra et al., 2003; Nomura et al., 2003; Shughrue et al., 1997). Not surprisingly, cycling ERß knockout mice show equivalent levels of lordosis behavior as found in wild-type $(\beta W T)$ mice on the day of behavioral estrus (Ogawa et al., 1999). However, the same study also reported that ER $\beta$ knockout mice unusually maintained high levels of receptivity on the day after behavioral estrus. This phenomenon was also reported in EB-primed ovariectomized $\beta E R K O$ mice tested at $30 \mathrm{hr}$ after progesterone treatment (Sano et al., 2018). Therefore, it is hypothesized that ER $\alpha$ in the VMH is absolutely necessary for the induction of lordosis behavior in female mice whereas ER $\beta$, expressed in brain regions other than the VMH (Alves et al., 2000; Helena et al., 2009; Nomura et al., 2005), may also be involved in the regulation of lordosis. A recent study using siRNA has investigated possible involvement of ER $\beta$-mediated action in one of the ER $\beta$-rich brain regions (Sano et al., 2018). Female mice treated with siRNA to site-specifically knockdown ER $\beta$ expression in the dorsal raphe nucleus (DRN) were ovariectomized and injected with EB ( $48 \mathrm{hr}$ before the first test) and progesterone. They were tested for lordosis behavior on twice consecutive days: the first test on the day mimicking behavioral estrus (i.e., 4-6 hr after progesterone treatment) and the second test on the day with the hormonal condition mimicking the day after behavioral estrus (i.e., $30 \mathrm{hr}$ after progesterone treatment). It was found that ER $\beta$ knockdown mice showed equivalent levels of lordosis behavior as control mice in the first test. However, unlike control mice, levels of lordosis behavior did not decline in ER $\beta$ knockdown mice in the second test. Therefore, it is concluded that ER $\beta$ in the DRN may be involved in the inhibitory 
regulation of sexual behavior specifically on the day after behavioral estrus in cycling female mice. Although the exact mechanism of this ERß-mediated action has not been specified, it is hypothesized that the serotonergic system may be involved. Previous studies have shown that a large proportion of ERß expressing neurons in the DRN are serotonergic (Nomura et al., 2005) and send projections to the hypothalamic regions (Lu et al., 2001) where activation of 5HT-1A receptors inhibit sexual behavior (Snoeren et al., 2014, Uphouse and Caldarola-Pastiszka, 1993). Furthermore, activation of ER $\beta$ by $17 \beta-E$ or ERß specific agonists, diarylpropionitrile (DPN) in ovariectomized female rats is reported to enhance mRNA expression of tryptophan hydroxylase 2 (TPH 2) in the DRN (Donner and Handa, 2009). Therefore, it is possible that ERß in the DRN may be mediating the inhibition of female sexual behavior by upregulating the activity of the serotonergic system within the DRN that further activates $5 \mathrm{HT}-1 \mathrm{~A}$ receptors expressed in hypothalamic regions.

In addition to genomic action, a number of studies have reported that non-genomic signaling in the arcuate nucleus of the hypothalamus (ARH) is also important for the initial inhibition of lordosis, which precedes the later activation by $17 \beta-E$ that is due to genomic signaling. Experiments from the Micevych laboratory demonstrated rapid signaling by the ER $\alpha$ at the plasma membrane in ARH neurons initiates a PKC cascade that leads to $\mu$-opioid receptor (MOR) internalization and activation. In the ARH, MOR internalization is inhibited by inhibitors to the metabotropic glutamate receptor (mGluR1) and caveolin-1 which demonstrates that, similar to the hippocampus, ER $\alpha$ is linked to mGluR1 via caveolin-1 (Dewing et al., 2007). Hence, preliminary nongenomic signaling in the ARH precedes genomic signaling in the $\mathrm{VMH}$ to facilitate lordosis behavior and can be thought of as a single integrated signaling pathway from membrane to nucleus. Though it is possible that both pathways operate independently, it was initially investigated if non-genomic signaling could influence genomic signaling i.e. transcription in neuroblastoma cells. Using a consensus ERE, it was demonstrated that a membrane limited $17 \beta-E$ conjugate (E2-BSA) that initiates non-genomic signaling can potentiate transcription that is driven by $17 \beta$-E bound to ER $\alpha$ (Vasudevan et al., 2001). In this integrated signaling pathway, potentiation was dependent on a number of kinases i.e. PKA, ERK and PI3K, whose activity can be increased rapidly by E2BSA. What is the molecular mechanism that couples non-genomic kinase activation to increased transcription? In a neuroblastoma cell line, overexpressed ER $\alpha$ mutants that could not be phosphorylated on kinase- specific sites (phospho-mutants) failed to show E2-BSA mediated transcriptional potentiation compared to wildtype $E R \alpha$, suggesting that phosphorylation of the $E R \alpha$ is critical to couple the non-genomic signaling initiated at the plasma membrane to transcription in the 
nucleus (Clark et al., 2014) (Figure 1). Similarly, in vivo, E2-BSA could potentiate lordosis that is driven by a brief pulse of $17 \beta-E$ in female ovariectomized rats (Kow and Pfaff, 2004). Importantly, E2-BSA alone could not induce lordosis or transcription, suggesting that for outputs that are critically dependent on estrogens, coupled signaling is important. Recently, this paradigm of discontinuous treatment of estrogens where the first pulse of E2-BSA is followed by $17 \beta-E$ potentiated the expression of the progesterone receptor in VMH neurons (Sa et al., 2014), required for lordosis.

What is the role of GPER1 in lordosis? Though GPER1 is expressed in the VMH and can activate PKA pathways that have been shown to potentiate lordosis, GPER1 activation alone did not facilitate lordosis in rats (Lebesgue et al., 2009). However, in ovariectomized mice, GPER1 activation by the use of a selective GPER1 agonist, G-1, followed by progesterone in a classic priming paradigm could facilitate lordosis, similar to EB administration. Specificity was demonstrated by the use of a specific GPER1 antagonist, G-15 that could block the G-1 facilitation of lordosis. Moreover, G-15 also decreased but not completely abolished the increase in lordosis seen with EB (Anchan et al., 2014), suggesting that GPER1 contributes, but is not the sole mediator of lordosis. It is not clear if this is a genuine species difference; both rats and mice express GPER1 in high levels in the hypothalamus (Hazell et al., 2009). In the adult hamster, GPER1 expression, as measured by RT-PCR, was higher in females in the hypothalamus than in males while GPER1 expression was higher in the amygdala of adult males compared to females (Canonaco et al., 2008). This suggests that GPER1 expression is variable and could be sexually dimorphic depending on the species. It is worth noting that GPER1 activation in rats primed with a low dose of EB could also facilitate lordosis, by releasing the initial inhibition that was mediated by activated MOR in the ARH (Long et al., 2014). The long-time scales used in all these experiments that measure lordosis behavior do not allow us to infer if GPER1 action is solely non-genomic or if activation of GPER1 regulates transcription i.e. integrated signaling which in turn facilitates lordosis.

What are the molecular mechanisms by which EB activates lordosis? One mechanism that occurs in both the ARH and $\mathrm{VMH}$ is the increase in dendritic spines and presumably synaptic plasticity (Christensen et al., 2011). The increase in dendritic spines is itself a process that depends on both nongenomic and genomic signaling by estrogens. In the ARH, mGluR1-ER $\alpha$ rapid signaling leads to ERK and PKC activation which, within 1 hour, activate LIMK, a kinase that phosphorylates cofilin. Phosphorylated cofilin that is inactive allows for the establishment of new spines (Meng et al., 2002). Administration of EB to ovariectomized rats results in immature, less stable filopodial spines within 4 hours which finally culminate in more stable, mushroom spines at 48 hours in the $\mathrm{ARH}$. In the $\mathrm{VMH}, \mathrm{EB}$ administration 
increases spines (Calizo and Flanagan-Cato, 2000) though the role of non-genomic signaling in this nucleus is not known. The role of GPER1 in spinogenesis in both these nuclei are not known but GPER1mediated spinogenesis occurs in the hippocampus within time frames that imply non-genomic signaling without transcription is sufficient for this phenomenon (Refer to Section 4 for details). Unpublished data by the Vasudevan laboratory shows that GPER1 contributes to increased spinogenesis mediated by $\mathrm{EB}$ in the $\mathrm{VMH}$ and also increases dendritic arbor in the $\mathrm{VMH}$. Similar to EB-mediated increases in the diameter of the spine head on pyramidal neurons in the female mouse hippocampus that is important for spatial memory (Li et al., 2004), GPER1 signaling in the hypothalamus may also change dendritic spine shape from immature filapodial spines to mushroom shaped spines that drive lordosis. However, this remains to be shown experimentally. This may provide an explanation for the puzzling observation that VMH neurons that showed increased spine density on EB administration did not express ER $\alpha$ (Calizo and Flanagan-Cato, 2000). 17 $\beta$-E could also increase immature spines rapidly via non-genomic signaling pathways such that PI3K so that neurons can respond with greater efficiency to a subsequent stimulus and stabilize the nascent spines. Though this two-step wiring has been shown to occur in cortical neurons, it is unknown if this occurs in the hypothalamus (Srivastava et al., 2008).

\subsection{Male sexual and aggressive behavior}

Studies with knockout mice revealed that ER $\alpha$ and ER $\beta$ may also be involved in the expression of male social behaviors such as sex and aggression. Male sexual behavior such as ultrasonic vocalization, mounts, intromissions and ejaculations, were greatly reduced or completely abolished in the single ER $\alpha$ knockout (Ogawa et al., 1997; Ogawa et al., 1998b) (Wersinger et al., 1997), double ER $\alpha$ and ERß knockout (Ogawa et al., 2000), and neuron specific ER $\alpha$ knockout mice (Sano et al., 2013b). In contrast, disruption of ERß did not affect male sexual behavior in both gonadally intact and EB-treated mice (Nomura et al., 2006; Ogawa et al., 1999). Therefore, activation of functional ER $\alpha$, but not ER $\beta$, by $17 \beta-E$ as the aromatization product of testosterone is necessary for the expression of male sexual behaviors.

Male aggressive behaviors, tested in a resident-intruder paradigm toward an olfactory bulbectomized male intruder mouse, were also completely abolished in ER $\alpha$ knockout, ER $\alpha$ and ER $\beta$ double knockout and neuron-specific ER $\alpha$ knockout (Nomura et al., 2006; Ogawa et al., 1999; Ogawa et al., 2000; Ogawa et al., 1998b; Sano et al., 2013b) mice. Unlike for sexual behavior, aggressive behavior was potentiated in ERß knockout mice in an age- and experience-dependent manner. Increase in the levels of aggression by ER $\beta$ deletion was most clearly shown in mice during the adolescent period. Male 
aggressive behavior first appears at the time of puberty onset around 5-6weeks of age (Tsuda et al., 2011). ER $\beta$ knockout mice were more aggressive than $\beta W T$ mice at 5 weeks of age (Nomura et al., 2002; Tsuda et al., 2014). Once they were sexually mature, genotype differences in the levels of aggression were no longer obvious unless mice were treated with EB or were instigated prior to the aggression test. EB treatment induced significantly higher levels of aggression in gonadectomized ER $\beta$ knockout mice than in WT mice (Nomura et al., 2006). Gonadally intact ER $\beta$ knockout mice were more easily irritated by exposure to an opponent male mouse (unpublished observations). Collectively, these findings suggest that ER $\alpha$ activation is necessary for the induction of male aggressive behavior whereas ER $\beta$ activation may inhibit aggressive behavior induced by ER $\alpha$ and/or the AR.

It is obvious that classical studies using global knockout mouse models have certain limitations to specify the time (during development vs in adults) and brain site(s) responsible for behavioral effects induced by disruption of each isoform of the ER. Among a number of regions constituting the neural network for social behaviors, responsible site(s) for the estrogenic regulation of sexual and aggressive behaviors have been determined by site-specific ER gene silencing. Sexual behavior was reduced by ER $\alpha$ silencing in the $\mathrm{VMH}$ or in the MPOA, whereas aggressive behavior was reduced by ER $\alpha$ silencing in the VMH only (Sano et al., 2013a). Considering the fact that all mice were tested as gonadally intact animals, these findings suggest that $E R \alpha$ activation in the targeted brain area at the time of behavioral testing in adults is essential for full expression of male-type social behaviors. Therefore, it was concluded that ER $\alpha$ activation in the $\mathrm{VMH}$ is necessary for both sexual and aggressive behavior in male mice. However, it is not yet determined whether the same neurons are responsible for the regulation of both behaviors. Optogenetic stimulation of $\mathrm{ER} \alpha$ expressing neurons in the $\mathrm{VMH}$ revealed neuronal populations which were activated during sexual behaviors, but inhibited during aggressive behaviors study (Lee et al., 2014; Lin et al., 2011).

Silencing of ER $\alpha$ in the MeA, the brain region implicated in social information processing and estrogenic regulation of male sexual behavior (Huddleston et al., 2006; Wood et al., 2001), has no effect on the expression of sexual and aggressive behaviors (Sano et al., 2013a). A recent study using MeAspecific ER $\alpha$ suppression with antisense also showed that sexual behavior was not affected in gonadally intact male rats (Paisley et al., 2012). As for the ERB, knockdown in the MeA as well as MPOA has no apparent effect on sexual and aggressive behaviors (Nakata et al., 2016). This study, however, has reported that ER $\beta$ knockdown in the MeA disrupts sexual preference for receptive females over nonreceptive females in male mice. 
So far, these studies manipulated site-specific activation of ER by $17 \beta-E$ only in adulthood. A recent study has reported that site-specific manipulation of ER $\alpha$ expression in sexually immature male mice has different effects (Sano et al., 2016) than in adult mice. Pre-pubertal (21days old) silencing of $E R \alpha$ in the MeA significantly reduces both sexual and aggressive behavior in adulthood. The siRNA used in this study irreversibly knocked down ER $\alpha$ expression in transfected cells. However, the same treatment in the adult does not affect male-type sexual and aggressive behavior (Sano et al., 2013a). Therefore, it is concluded that ER $\alpha$ activation in the MeA during pubertal period is crucial for male mice to fully express their male-type social behaviors in adulthood. Furthermore, pre-pubertal knockdown of $E R \alpha$ in male mice reduces the number of neurons in the MeA to the levels of female mice (Sano et al., 2016). It is expected that future studies will elucidate the exact mechanisms of ER $\alpha$ action that results in full masculinization of neural networks for male-type social behavior, during the pubertal period.

\section{Estrogenic regulation of social recognition and social learning.}

\subsection{Social recognition}

Social recognition allows members of a group to distinguish conspecifics on the basis of various characteristics. Through social recognition animals can assign others to specific categories (e.g. sex, reproductive status, familiarity, kinship, hierarchical status, health, specific individual) and utilize this information to adaptively adjust their behavior to their social context. For example, on the bases of social recognition processes a male may attempt to mate with an estrous female, whereas he may be aggressive towards unfamiliar male intruders to his territory. The most commonly studied form of social recognition in the laboratory is familiarity recognition (hereinafter referred to as "social recognition"). Although there exist a few different ways of assessing familiarity recognition, in all of them an animal's social investigative responses towards familiar or unfamiliar conspecifics are observed. When an unfamiliar conspecific is investigated more than a familiar conspecific, either within a choice test or upon subsequent social exposures, it is inferred that the familiar conspecific has been recognized (reviewed and discussed in (Choleris et al., 2009; Engelmann et al., 1995; Gheusi et al., 1994; Johnston, 2003).

The involvement of estrogens in social recognition has been repeatedly described (reviewed in (Ervin et al., 2015a; Lymer et al., 2018). Female social recognition skills vary with the estrous cycle (Sanchez-Andrade and Kendrick, 2011), are reduced by ovariectomy, and can be restored with estrogens alone and with estrogens and progesterone replacement (Hlinak, 1993; Spiteri and Agmo, 2009; Tang et 
al., 2005). Investigations with mice with the gene for specific ERs specifically "knocked out", showed that $E R \alpha$ is necessary for social recognition in males and females (Choleris et al., 2003; Choleris et al., 2006; Imwalle et al., 2002; Sanchez-Andrade and Kendrick, 2011), whereas ER $\beta$ seems less or not involved, affecting behavior in the social recognition test in ways that appear not directly related to social recognition (e.g. by generally regulating social investigation or social anxiety) (Choleris et al., 2003; Choleris et al., 2006; Sanchez-Andrade and Kendrick, 2011); discussed in (Ervin et al., 2015a). The investigations with ER knockout mice, thus, implicated ER $\alpha$ in social recognition. Whether or not this function of $E R \alpha$ is due to organizational or activational effects of estrogens has not been investigated in the knockout mice. More recently, studies with hormonal and/or ER-specific pharmacological manipulations investigated the activational very rapid (likely non-genomic) mechanisms underlying estrogens' facilitation of social recognition in adults. In a "difficult" task (with reduced opportunities to investigate ovariectomized social stimuli during a training phase) where ovariectomized female mice typically showed no social recognition, a single subcutaneous injection with $17 \beta-E$ was capable of restoring social recognition within 40 minutes of treatment (Phan et al., 2012). Using the same difficult task and timing of administration, both a selective ER $\alpha$ and a GPER agonist, but not an ER $\beta$ agonist, were also capable of restoring social recognition in ovariectomized mice, suggesting ER-specific regulation of social recognition via rapid, non-genomic, mechanisms (Gabor et al., 2015; Phan et al., 2012).

Subsequent studies have investigated the brain regions involved in estrogenic mediation of social recognition in adults. Long-term inhibition of the expression of the ER $\alpha$ gene in the medial posterodorsal amygdala (but not in the $\mathrm{VMH}$ ) with shRNA blocked social recognition in female rats (Spiteri et al., 2010). Similarly, administration of $17 \beta-E$, and agonists for $E R \alpha, E R \beta$, and GPER into the MeA all facilitated or enhanced social recognition in ovariectomized mice within 40 min of treatment (Lymer et al., 2018), suggesting that all three ERs in the MeA are capable of mediating social recognition via rapid non-genomic mechanisms. Intriguingly, when the same treatments were administered in the dorsal hippocampus, $17 \beta-E$ and ER $\alpha$ and GPER agonists each rapidly facilitated social recognition in ovariectomized mice, whereas an ER $\beta$ agonist did not facilitate social recognition, not even at doses that facilitated spatial recognition (Lymer et al., 2017; Phan et al., 2015). Thus, different brain regions can mediate estrogenic rapid facilitation of social recognition, with some region- and ER- specificity. In particular, the involvement of ER $\beta$ seems different in the dorsal hippocampus (not involved) and the MeA (involved). 
Systemic and dorsal hippocampal treatments with $17 \beta-E$ and the ER $\alpha$ and GPER agonists also rapidly increased the number of dendritic spines in the CA1 subregion (Gabor et al., 2015; Phan et al., 2012; Phan et al., 2011; Phan et al., 2015), and decreased AMPA activity in dorsal hippocampal CA1 neurons of ovariectomized mice (Phan et al., 2015), suggesting that rapid induction of initially silent, immature, dendritic spines may mediate estrogenic rapid enhancement of social as well as other types of recognition in the dorsal hippocampus. The possible downstream mechanisms of these effects are only beginning to be investigated. Recently, with infusions of membrane impermeable BSA-conjugated $17 \beta-E$ it has been shown that in the dorsal hippocampus rapid facilitation of social recognition by $17 \beta-E$ in adult ovariectomized mice is due to membrane-initiated mechanisms (Kunn et al., 2017). In addition, it was found that in the dorsal hippocampus the extracellular signal-regulated kinase (ERK), and the phosphoinositide 3-kinase (PI3K)/Akt (a.k.a. protein kinase B or PKB), both mediate $17 \beta$-E and ER $\alpha$ facilitatory effects. Conversely, the PI3K, but not ERK, pathway mediates GPER facilitated social recognition (Sheppard et al., 2017a; Sheppard et al., 2017b); reviewed in (Paletta et al., 2018). It was also found that the nonapeptide oxytocin, which is necessary for social recognition in males and females (Ferguson et al., 2001; Ferguson et al., 2000) (Choleris et al., 2003; Choleris et al., 2006), may be downstream of rapid estrogenic enhancement of social recognition. Infusion of $17 \beta-E$ in the oxytocinproducing paraventricular nucleus of the hypothalamus rapidly restored social recognition in adult ovariectomized mice in the difficult task and this effect could be blocked by infusion of a subeffective dose (i.e. that per se would not impair social recognition) of an oxytocin receptor antagonist in the MeA (Paletta et al., 2017) reviewed in (Paletta et al., 2018). The specific ERs mediating this estrogen/oxytocin interplay in the regulation of social recognition are currently unknown. Both ER $\beta$ and GPER are expressed in the paraventricular nucleus of the hypothalamus (Hazell et al., 2009; Mitra et al., 2003) and ER $\beta$ on oxytocinergic neurons in the other main nucleus of oxytocin production, the supraoptic nucleus, can stimulate the release of oxytocin within 5 min of estradiol application (Wang et al., 1995). Thus, both ER $\beta$ and GPER are well placed as possible mediators of the rapid estrogen/oxytocin interplay in the facilitation of social recognition. Overall, these recent findings show that estrogens can rapidly facilitate social recognition in adult females via the activation of specific cell kinase responses, as well as by acting upon oxytocin, possibly by inducing its release from cellular storage. Whether the same cell signaling pathways mediate the estrogenic rapid enhancement of social recognition in regions other than the dorsal hippocampus remains to be investigated.

\subsection{Social Learning}


Social learning is "learning that is influenced by observation of, or interaction with, another animal (typically a conspecific) or its products" (such as odor cues; (Box, 1984; Galef, 1988; Heyes, 1994). By learning from others, animals can reduce the need for learning through personal experience that typically carries some degree of risk. For example, in order to learn whether or not an unknown food item is safe to eat, an animal needs to ingest it, wait for physiological responses (e.g. sickness), then either develop aversion to and avoidance of it or incorporate it in its diet. Through social learning these steps can be skipped. If a conspecific that has ingested a novel food safely returns to the group, others can acquire information about that food and safely consume it when they encounter it at a later time (Galef, 1989; Galef and Wigmore, 1983). The social transmission of food preferences (STFP) has been described in a number of animal species and has been extensively researched in the laboratory (reviewed in (Choleris et al., 2009) (Ervin et al., 2015a; Matta et al., 2016a), making it an excellent model for the investigation of the neurobiological bases of social learning.

A role for estrogens and their receptors in social learning in the STFP has been shown, via both delayed and rapid mechanisms. Although historically most studies have focused on one sex (mostly males), the few that compared the sexes often find a female advantage in social learning (reviewed in (Ervin et al., 2015a; Matta et al., 2016a) (Choleris and Kavaliers, 1999), suggesting a facilitatory role for female hormones. Similarly, an enhancing effect of pregnancy in the STFP in rats (Fleming et al., 1994) and gerbils (Choleris et al., 2012) and fluctuations in STFP performance over the estrous cycle in mice (Choleris et al., 2011), all point at a role for estrogens and/or progestins. Systemic administration of EB or an ER $\beta$ agonist 48 or $72 \mathrm{hr}$ before testing prolonged a socially acquired food preference in adult ovariectomized mice, whereas an ER $\alpha$ agonist blocked it (Clipperton et al., 2008), suggesting opposing roles for $E R \alpha$ and $E R \beta, E R \beta$ facilitating and $E R \alpha$ inhibiting social learning via delayed, likely genomic, mechanisms. Estrogens facilitate social learning in the STFP also via rapid mechanisms. Intriguingly, the rapid effects do not fully overlap with the delayed effects. Subcutaneous treatment with $17 \beta$-E restored the social acquisition of a food preference within 45 minutes of administration, under conditions where ovariectomized adult mice would not normally show social learning (Ervin et al., 2015b). The administration of a GPER agonist similarly rapidly facilitated social learning, whereas ER $\alpha$ and ER $\beta$ agonists neither rapidly facilitated nor blocked social learning in the STFP in ovariectomized adult mice (Ervin et al., 2015b). Thus, different ERs are involved in estrogenic facilitation of social learning, ER $\beta$ via delayed mechanisms and GPER via rapid mechanisms.

The brain regions involved in the estrogenic enhancement of social learning remain unknown. 
The dorsal hippocampus and the basolateral amygdala appeared strong candidate because both of these regions are involved in social learning and express the ERs (Carballo-Marquez et al., 2009; Hazell et al., 2009; Matta et al., 2017; Mitra et al., 2003; Winocur, 1990). However, infusions of a range of doses of $17 \beta-E$ in these regions did not facilitate the STFP (Ervin et al., 2014) reviewed in (Ervin et al., 2015a), not even doses that in the dorsal hippocampus had a strong facilitatory effect on social recognition (Phan et al., 2015). Thus, it seems likely the rapid facilitation of social learning by estrogens is secondary to their action on other neurochemical systems in the brain. For example, clear sex differences are being found in the involvement of dorsal hippocampal dopamine receptors in the STFP (Matta et al., 2017; Matta et al., 2016b) reviewed in (Paletta et al., 2018), suggesting estrogens may promote social learning by rapidly enhancing the activity of dopamine or other neurochemical systems known to mediate the STFP (e.g. acetylcholine, (Carballo-Marquez et al., 2009) (Gold et al., 2011), possibly by acting on the synthetizing neurons that project to brain regions involved in social learning.

\subsection{Estrogens facilitate different types of social cognition differently}

Studies reviewed in the two parts above show a clear facilitation of social cognition by estrogens in adult females. The mechanisms of this facilitation are, however, different for social recognition and social learning and can also be different for rapid and delayed mechanisms. Social recognition is rapidly facilitated by ER $\alpha$ and GPER, whereas ER $\beta$ so far has been shown to facilitate it only in the MeA. Conversely, social learning is enhanced by ER $\beta$ (delayed effect, not rapid) or GPER (rapid effect) and is either blocked (delayed effect) or unaffected (rapid effect) by ER $\alpha$. The brain regions involved also appear to be different for estrogenic facilitation of social recognition and social learning. The dorsal hippocampus mediates the rapid facilitation of social recognition but not of social learning by estrogens (reviewed above and in (Paletta et al., 2018). Thus, even though we often talk about social cognition collectively, the two types of social cognition most studied, learning about others (social recognition) and learning from others (social learning), though both facilitated by estrogens, are showing intriguingly different underlying mechanisms, both in terms of the ERs involved and whether the effects are delayed or rapid. Future research will need to further clarify overlapping and non-overlapping mechanisms of estrogenic facilitation of different types of social cognition. Recent findings are showing that estrogens can facilitate social cognition through an interplay with other neurochemical systems in the brain (e.g. estradiol/oxytocin and social recognition). Thus, future research should investigate the implications for social cognition of the rapid interactions of estrogens with other neurobiological systems. 


\section{Estrogenic regulation of anxiety-related behavior}

\subsection{GPER1 activation leads to different outcomes in males and female mice}

A number of the behaviors described in Sections 3 and 4 can be influenced by state anxiety. State anxiety is the unpleasant arousal in the face of impending dangers, as opposed to trait anxiety which is a stable inheritable difference in the ability to respond to environmental circumstances. One possibility is that rapid actions of estrogens modulate state anxiety which in turn can fine tune social behaviors that are driven by genomic signaling over longer time scales. Similar to other studies described in this review where GPER1 activation facilitates social cognition in female mice over shorter time scales that are commensurate with non-genomic signaling, GPER1 activation in castrated male mice was shown to be anxiolytic in males but not in females. In the elevated plus maze, G-1 administration to gonadectomized male mice increased time and distance in the open arms as compared to control within 30 minutes of administration, suggesting that GPER1 agonism is sufficient to change state anxiety (Hart et al., 2014). In male mice, G-1 administration increased the phosphorylation of ER $\alpha$ at an ERK site i.e. serine at position 118 in the ventral hippocampus within 30 minutes though ERK activation itself could not be detected in the hippocampus in male mice at this time point (Hart et al., 2014). In female mice, ERK activation by G-1 could be detected within 30 minutes in the dorsal, but not the ventral hippocampus (Hart et al., 2014). The phosphorylation of ER $\alpha$ in the male mouse ventral hippocampus by GPER1, presumably activated by G-1, is one of the first examples of ER $\alpha$-GPER1 crosstalk.

In contrast to these studies where the phenotype i.e. state anxiety was studied within $\mathbf{3 0}$ minutes, G-1 administration to ovariectomized female mice and intact male mice increased anxiety in the elevated plus maze and the open field test, with males showing more sensitivity to G-1 administration than females (Kastenberger et al., 2012). Consistent with this data, GPER1 knockout mice showed reduced anxiety, with the effects being more pronounced in males than females (Kastenberger and Schwarzer, 2014). The differences in this data compared to the previous study (Hart et al., 2014) could be due to differing doses or time frames; the expression of GPER1 as measured by in situ hybridization of RNA does not show sexual dimorphism in either rats or mice (Hazell et al., 2009). Nevertheless, these studies suggest that males may be more sensitive to the rapid effects of GPER1 activation, at least in the ventral hippocampus than females; this may affect state anxiety and consequently, behaviors that depend on state anxiety. Consistent with this idea, in the ventral hippocampus, phosphorylated ERK is higher in males than females, 60 minutes after fear conditioning 
(Gresack et al., 2009). It is also possible that ERK signaling is less important in the hippocampus in males rather than in females. For example, estrogens do not increase the level of activated ERK in males in the dorsal hippocampus, as compared to females and activated ERK does not seem to be required for object memory consolidation (Koss et al., 2017). Conversely, the G-1 mediated upregulation of activated ERK in the dorsal hippocampus in females may be important in the GPER1 facilitation of social but not object memory, as shown by the Choleris Lab (Section 4). Also, GPER1 acts to increase memory consolidation in female mice via the JNK pathway, not the ERK pathway (Kim et al., 2016); it remains to be seen if this pathway is important in the ventral hippocampus of males to decrease anxiety. These differences in signaling pathways and receptor activation between sexes underline the importance of context for hippocampal-dependent tasks.

\section{Is estrogenic regulation of sex-typical social behaviors species-specific?}

\subsection{Animal models of sex behavior, aggression and social cognition}

Animal models have been utilized to study social behaviours for several reasons: a) as a model for steroid hormone action in the brain, b) as a model of sexual differentiation if the behaviour is sex typical c) for the sake of animal behaviour itself and d) for a minority of researchers, as a model for the comparable human behaviour. Rats and mice are the most common mammalian models. They are easily maintained, have stereotypical behaviours that are responsive to steroid hormones, and can be genetically manipulated. Rats, mice and hamsters are common models to study the hormonal control of lordosis behavior and show optimal proceptive and receptive aspects of lordosis when both estrogens and progesterone are present (Pfaff, 1980; Steel, 1983). Though the neuroendocrine circuitry and in particular reward mechanisms of lordosis appear to be conserved across mammalian species, there are differences between reflex and spontaneous ovulators. For example, the rabbit shows reduced but not absent lordosis after ovariectomy and does not show the stimulatory effect of progesterone (Beyer et al., 2007). In another reflex ovulator, the ferret, the serotonin receptor 5-HT1A agonist 8-hydroxy-2-(din-propylamino)tetralin (8-OH-DPAT) facilitates lordosis in EB primed ovariectomized females in contrast to the inhibition seen in the female rat (Paredes et al., 1994). Over the last two decades, the use of conditioning and preference paradigms in rodents has tested facets of appetitive sexual behaviour that have human equivalents (Pfaus et al., 2003). However, in the human female, sexual motivation is thought to be adrenal androgen driven as evidenced by the off-label use of testosterone for disorders of sexual desire in women. However, recently, estrogens-only therapies for postmenopausal women have been shown to increase desire; this is similar to the estrogenic regulation of sexual motivation in female 
rodents (Cappelletti and Wallen, 2016). Interestingly, polymorphisms in the ER $\alpha$ and an ER $\alpha$ upregulated gene, the oxytocin receptor are correlated with increased sexual motivation and arousal (Armeni et al., 2017).

Species differences in brain expression of the nonapeptide systems oxytocin and vasopressin have been shown in monogamous and polygamous vole species and they appear related to the capability of developing pair bonds after mating in monogamous species (reviewed in Gobrogge \& Wang, 2015). Because pair bonding in monogamous species requires the cognitive skill of individual recognition (Zheng et al., 2013), similar species differences in the neurobiological mechanisms underlying social recognition may be hypothesized. To be best of our knowledge, the regulation of social recognition by estrogens has so far only been shown in rats and mice, with no species differences having been demonstrated. Whether estrogenic regulation of social recognition is similar in species with different social systems remains to be investigated. ER $\alpha$ involvement in social behavior has been hypothesized in monogamous and polygamous Peromyscus species on the basis of brain receptor distribution (Cushing, 2016). Medial amygdala ER $\alpha$ regulation of prosocial behavior in male monogamous and polygamous voles has been shown (Cushing et al., 2008). Intriguingly, specific polymorphisms in the ER $\alpha$ and $E R \beta$ genes are associated with enhanced social memory in women (Karlsson et al., 2016). These findings suggest estrogenic regulation of social recognition may be similar across species with different social and mating systems. Similarly, social learning has been shown in multiple species, from invertebrates to vertebrates (reviewed in (Ervin et al., 2015a; Matta et al., 2016a). Whether or not estrogens similarly regulate it in different species is, to the best of our knowledge, currently unknown, but it certainly deserves further investigation.

\section{Future perspectives}

Several outstanding questions remain, despite the progress made in understanding the contribution of the receptors in classical estrogenic-driven sex-specific behaviors, such as lordosis or aggression. For example, the role of $E R \beta$, particularly in the developmental period remains underexplored, though this will be certainly facilitated by recently developed ER $\beta$-cre mouse where crerecombinase is expressed in ER $\beta$ neurons and by the availability of a mouse where ER $\beta$ expression is tagged by a fluorescent reporter. Similarly, whether organizational effects contribute to the estrogenic regulation of social cognition remains to be investigated. Secondly, in nuclei where both ER $\alpha$ and ER $\beta$ are equally expressed, their relative contribution to different behaviors is not clear even though recent 
investigations on social recognition and social learning are showing that ER-specific and brain regionspecific mechanisms may be at play. Thirdly, in stereotypical behaviors which have several steps in a sequence, the relative contribution of non-genomic signaling to genomic signaling to these different steps is still being investigated. The role of ER $\alpha$ phosphorylation or other modifications, including DNA methylation, that are driven by non-genomic signaling could be important in both organizational and activational effects of estrogens that drive social behaviors. This has been underexplored in vivo. Lastly, not much is known about crosstalk between the different ERs and estrogens and other neurochemical systems in different brain regions which almost certainly modulates the final output.

\section{Declaration:}

The authors wish to declare that they do not have any conflicts of interest. 


\section{Legends}

Figure 1: Non-genomic signaling can potentiate the effects of genomic signaling. In this model, initial nongenomic signaling from a mER protein by estrogens (E2-BSA or the natural ligand, $17 \beta-E$ ) at the plasma membrane can activate several kinases and calcium. The identity of the $m E R$ is debated with GPER1, ER $\alpha$ and ER $\beta$ all seen as major candidates. ER?? phosphorylation, denoted in this figure by $P$, presumably as a result of kinase activation is important to potentiate transcription (genomic signaling) from genes that have EREs (Clark et al., 2014) in neuroblastoma cells. It is important to note that there is no strict demarcation between genomic and non-genomic signaling and such an integrated signaling pathway can conceivably increase spine density $(S)$ and regulate social behaviors. Apart from integrated signaling, non-genomic signaling alone has been implicated in spinogenesis in the female mouse dorsal hippocampus (Section 4.1) though the molecular mechanisms remain to be elucidated.

Figure 2: Roles of gonadal sex steroids in the sexual differentiation of the brain in rodent models. Testosterone $(T)$ secreted from the testes in the perinatal and peripubertal periods acts to masculinize and defeminize the sexually undifferentiated brain. T affects the brain via the androgen receptor. In addition, $T$ affects the brain via the estrogen receptor after conversion to estradiol (17 $\beta-E)$, although the roles of $17 \beta-E$ during the peripubertal period in organization of the male brain remains to be fully uncovered. $17 \beta-E$ secreted from the ovaries in the peripubertal period acts to organize the female brain. In addition to sex steroids, sex chromosome genes expressed in the brain also play an important role in the sexual differentiation of the brain.

Figure 3: Location and sex difference in sexually dimorphic nuclei in the BNST and MPOA of mice. The rostral part of the mPOA contains the AVPV, which is larger in size and has more neurons in females than in males (Bleier et al., 1982; Kanaya et al., 2014; Sumida et al., 1993). The BNST and the caudal part of the MPOA have a cluster of neurons expressing calbindin-D28K. Here the clusters in the BNST and mPOA are termed CALB-BNSTp and CALB-SDN, respectively. The CALB-BNSTp and CALB-SDN in male mice are consisted of more calbindin-D28K neurons and larger in size compared to those in female mice (Gilmore et al., 2012; Morishita et al., 2017; Orikasa and Sakuma, 2010). The CALB-BNSTp is a part of the BNSTp that can be identified by Nissl staining and shows male-dominant sex differences in the volume and neuron number (Forger et al., 2004; Tsukahara et al., 2011). Although the BNSTp itself exhibits male-dominant sex differences in the morphology, the ventral part of the BNSTp (BNSTpv) is larger in size and contains greater number of non-calbindin-D28K neurons in female mice than in male 
mice (Morishita et al., 2017).

Acknowledgements: This work was supported by JSPS Grant-in-Aid for Scientific Research to S.O. (15H05724 and 17H05549) and to ST (17K08567), NSERC Discovery grant (400212) to EC and NSF CAREER IOS-1053716 and University of Reading startup fund to NV.

\section{References}

Ahmed, E.I., Zehr, J.L., Schulz, K.M., Lorenz, B.H., DonCarlos, L.L., Sisk, C.L., 2008. Pubertal hormones modulate the addition of new cells to sexually dimorphic brain regions. Nat Neurosci 11, 995-997. Alexander, A., Irving, A.J., Harvey, J., 2016. Emerging roles for the novel estrogen-sensing receptor GPER1 in the CNS. Neuropharmacology.

Allieri, F., Spigolon, G., Melcangi, R.C., Collado, P., Guillamon, A., Gotti, S., Panzica, G.C., 2013. Androgen receptor deficiency alters the arginine-vasopressin sexually dimorphic system in Tfm rats. Neuroscience 253, 67-77.

Alves, S.E., McEwen, B.S., Hayashi, S., Korach, K.S., Pfaff, D.W., Ogawa, S., 2000. Estrogen-regulated progestin receptors are found in the midbrain raphe but not hippocampus of estrogen receptor alpha (ER alpha) gene-disrupted mice. The Journal of comparative neurology 427, 185-195.

Anbalagan, M., Huderson, B., Murphy, L., Rowan, B.G., 2012. Post-translational modifications of nuclear receptors and human disease. Nucl Recept Signal 10, e001.

Anchan, D., Gafur, A., Sano, K., Ogawa, S., Vasudevan, N., 2014. Activation of the GPR30 Receptor Promotes Lordosis in Female Mice. Neuroendocrinology 100, 71-80.

Ariazi, E.A., Brailoiu, E., Yerrum, S., Shupp, H.A., Slifker, M.J., Cunliffe, H.E., Black, M.A., Donato, A.L., Arterburn, J.B., Oprea, T.I., Prossnitz, E.R., Dun, N.J., Jordan, V.C., 2010. The G protein-coupled receptor GPR30 inhibits proliferation of estrogen receptor-positive breast cancer cells. Cancer research 70, 11841194.

Armeni, A.K., Assimakopoulos, K., Marioli, D., Koika, V., Michaelidou, E., Mourtzi, N., Iconomou, G., Georgopoulos, N.A., 2017. Impact of estrogen receptor alpha gene and oxytocin receptor gene polymorphisms on female sexuality. Endocr Connect 6, 44-52.

Arnold, A.P., 2014. Conceptual frameworks and mouse models for studying sex differences in physiology and disease: why compensation changes the game. Experimental neurology 259, 2-9.

Bakker, J., Honda, S., Harada, N., Balthazart, J., 2002. The aromatase knock-out mouse provides new evidence that estradiol is required during development in the female for the expression of sociosexual behaviors in adulthood. J Neurosci 22, 9104-9112.

Beyer, C., Hoffman, K.L., Gonzalez-Flores, O., 2007. Neuroendocrine regulation of estrous behavior in the rabbit: similarities and differences with the rat. Horm Behav 52, 2-11. 
Bleier, R., Byne, W., Siggelkow, I., 1982. Cytoarchitectonic sexual dimorphisms of the medial preoptic and anterior hypothalamic areas in guinea pig, rat, hamster, and mouse. The Journal of comparative neurology 212, 118-130.

Boulware, M.I., Kordasiewicz, H., Mermelstein, P.G., 2007. Caveolin proteins are essential for distinct effects of membrane estrogen receptors in neurons. J Neurosci 27, 9941-9950.

Box, H.O., 1984. Primate behaviour and social ecology. Chapman and Hall, London; New York.

Brailoiu, E., Dun, S.L., Brailoiu, G.C., Mizuo, K., Sklar, L.A., Oprea, T.I., Prossnitz, E.R., Dun, N.J., 2007. Distribution and characterization of estrogen receptor $\mathrm{G}$ protein-coupled receptor 30 in the rat central nervous system. J Endocrinol 193, 311-321.

Bridges, R.S., 2015. Neuroendocrine regulation of maternal behavior. Front Neuroendocrinol 36, $178-$ 196.

Brock, O., Baum, M.J., Bakker, J., 2011. The development of female sexual behavior requires prepubertal estradiol. J Neurosci 31, 5574-5578.

Brown-Grant, K., 1975. A re-examination of the lordosis response in female rats given high doses of testosterone propionate or estradiol benzoate in the neonatal period. Horm Behav 6, 351-378.

Calizo, L.H., Flanagan-Cato, L.M., 2000. Estrogen selectively regulates spine density within the dendritic arbor of rat ventromedial hypothalamic neurons. J Neurosci 20, 1589-1596.

Campi, K.L., Jameson, C.E., Trainor, B.C., 2013. Sexual Dimorphism in the Brain of the Monogamous California Mouse (Peromyscus californicus). Brain Behav Evol 81, 236-249.

Canonaco, M., Giusi, G., Madeo, A., Facciolo, R.M., Lappano, R., Canonaco, A., Maggiolini, M., 2008. A sexually dimorphic distribution pattern of the novel estrogen receptor G-protein-coupled receptor 30 in some brain areas of the hamster. J Endocrinol 196, 131-138.

Cappelletti, M., Wallen, K., 2016. Increasing women's sexual desire: The comparative effectiveness of estrogens and androgens. Horm Behav 78, 178-193.

Carballo-Marquez, A., Vale-Martinez, A., Guillazo-Blanch, G., Marti-Nicolovius, M., 2009. Muscarinic transmission in the basolateral amygdala is necessary for the acquisition of socially transmitted food preferences in rats. Neurobiology of learning and memory 91, 98-101.

Choleris, E., Clipperton-Allen, A.E., Gray, D.G., Diaz-Gonzalez, S., Welsman, R.G., 2011. Differential effects of dopamine receptor D1-type and D2-type antagonists and phase of the estrous cycle on social learning of food preferences, feeding, and social interactions in mice. Neuropsychopharmacology 36, 1689-1702.

Choleris, E., Clipperton-Allen, A.E., Phan, A., Kavaliers, M., 2009. Neuroendocrinology of social information processing in rats and mice. Front Neuroendocrinol 30, 442-459.

Choleris, E., Clipperton-Allen, A.E., Phan, A., Valsecchi, P., Kavaliers, M., 2012. Estrogenic involvement in social learning, social recognition and pathogen avoidance. Front Neuroendocrinol 33, 140-159.

Choleris, E., Gustafsson, J.A., Korach, K.S., Muglia, L.J., Pfaff, D.W., Ogawa, S., 2003. An estrogendependent four-gene micronet regulating social recognition: a study with oxytocin and estrogen receptor-alpha and -beta knockout mice. Proc Natl Acad Sci U S A 100, 6192-6197.

Choleris, E., Kavaliers, M., 1999. Social learning in animals: sex differences and neurobiological analysis. Pharmacol Biochem Behav 64, 767-776.

Choleris, E., Ogawa, S., Kavaliers, M., Gustafsson, J.A., Korach, K.S., Muglia, L.J., Pfaff, D.W., 2006. Involvement of estrogen receptor alpha, beta and oxytocin in social discrimination: A detailed behavioral analysis with knockout female mice. Genes, brain, and behavior 5, 528-539.

Christensen, A., Dewing, P., Micevych, P., 2011. Membrane-initiated estradiol signaling induces spinogenesis required for female sexual receptivity. J Neurosci 31, 17583-17589.

Chung, W.C., Swaab, D.F., De Vries, G.J., 2000. Apoptosis during sexual differentiation of the bed nucleus of the stria terminalis in the rat brain. Journal of neurobiology 43, 234-243. 
Clark, S., Rainville, J., Zhao, X., Katzenellenbogen, B.S., Pfaff, D., Vasudevan, N., 2014. Estrogen receptormediated transcription involves the activation of multiple kinase pathways in neuroblastoma cells. J Steroid Biochem Mol Biol 139, 45-53.

Clemens, L.G., Gladue, B.A., 1978. Feminine sexual behavior in rats enhanced by prenatal inhibition of androgen aromatization. Horm Behav 11, 190-201.

Clipperton, A.E., Spinato, J.M., Chernets, C., Pfaff, D.W., Choleris, E., 2008. Differential effects of estrogen receptor alpha and beta specific agonists on social learning of food preferences in female mice. Neuropsychopharmacology 33, 2362-2375.

Coolen, L.M., Peters, H.J., Veening, J.G., 1996. Fos immunoreactivity in the rat brain following consummatory elements of sexual behavior: a sex comparison. Brain Res 738, 67-82.

Cox, K.H., Bonthuis, P.J., Rissman, E.F., 2014. Mouse model systems to study sex chromosome genes and behavior: relevance to humans. Front Neuroendocrinol 35, 405-419.

Cushing, B.S., Perry, A., Musatov, S., Ogawa, S., Papademetriou, E., 2008. Estrogen receptors in the medial amygdala inhibit the expression of male prosocial behavior. J Neurosci 28, 10399-10403.

Davis, P.G., McEwen, B., Pfaff, D.W., 1979. Localized behavioral effects of tritiated estradiol implants in the ventromedial hypothalamus of female rats. Endocrinology 104, 893-903.

del Abril, A., Segovia, S., Guillamon, A., 1987. The bed nucleus of the stria terminalis in the rat: regional sex differences controlled by gonadal steroids early after birth. Brain Res 429, 295-300.

Dewing, P., Boulware, M.I., Sinchak, K., Christensen, A., Mermelstein, P.G., Micevych, P., 2007. Membrane estrogen receptor-alpha interactions with metabotropic glutamate receptor 1a modulate female sexual receptivity in rats. J Neurosci 27, 9294-9300.

Dominguez, R., Dewing, P., Kuo, J., Micevych, P., 2013. Membrane-initiated estradiol signaling in immortalized hypothalamic N-38 neurons. Steroids 78, 607-613.

Dominguez, R., Micevych, P., 2010. Estradiol rapidly regulates membrane estrogen receptor alpha levels in hypothalamic neurons. J Neurosci 30, 12589-12596.

Dominguez-Ordonez, R., Garcia-Juarez, M., Lima-Hernandez, F.J., Gomora-Arrati, P., Blaustein, J.D., Etgen, A.M., Gonzalez-Flores, O., 2016. Estrogen receptor alpha and beta are involved in the activation of lordosis behavior in estradiol-primed rats. Horm Behav 86, 1-7.

Durazzo, A., Morris, J.A., Breedlove, S.M., Jordan, C.L., 2007. Effects of the testicular feminization mutation $(\mathrm{tfm})$ of the androgen receptor gene on BSTMPM volume and morphology in rats. Neurosci Lett 419, 168-171.

Engelmann, M., Wotjak, C.T., Landgraf, R., 1995. Social discrimination procedure: an alternative method to investigate juvenile recognition abilities in rats. Physiol Behav 58, 315-321.

Ervin, K.S., Lymer, J.M., Matta, R., Clipperton-Allen, A.E., Kavaliers, M., Choleris, E., 2015a. Estrogen involvement in social behavior in rodents: Rapid and long-term actions. Horm Behav 74, 53-76.

Ervin, K.S., Mulvale, E., Gallagher, N., Roussel, V., Choleris, E., 2015b. Activation of the G protein-coupled estrogen receptor, but not estrogen receptor alpha or beta, rapidly enhances social learning.

Psychoneuroendocrinology 58, 51-66.

Ervin, K.S., Paletta, P., Sawula, M., Moore, A., Sinclair, K., Phan, A., Choleris, E., 2014. Investigation of the roles of the hippocampus and basolateral amygdala in rapid estrogenic enhancement of social learning., Society for Neuroscience Annual Meting.

Feder, H.H., Whalen, R.E., 1965. Feminine Behavior in Neonatally Castrated and Estrogen-Treated Male Rats. Science 147, 306-307.

Feldman, R.D., Limbird, L.E., 2017. GPER (GPR30): A Nongenomic Receptor (GPCR) for Steroid Hormones with Implications for Cardiovascular Disease and Cancer. Annual review of pharmacology and toxicology 57, 567-584.

Ferguson, J.N., Aldag, J.M., Insel, T.R., Young, L.J., 2001. Oxytocin in the medial amygdala is essential for social recognition in the mouse. J Neurosci 21, 8278-8285. 
Ferguson, J.N., Young, L.J., Hearn, E.F., Matzuk, M.M., Insel, T.R., Winslow, J.T., 2000. Social amnesia in mice lacking the oxytocin gene. Nature genetics 25, 284-288.

Fleming, A.S., Kuchera, C., Lee, A., Winocur, G., 1994. Olfactory-based social learning varies as a function of parity in female rats. Psychobiol 22, 37-43.

Forger, N.G., Rosen, G.J., Waters, E.M., Jacob, D., Simerly, R.B., de Vries, G.J., 2004. Deletion of Bax eliminates sex differences in the mouse forebrain. Proc Natl Acad Sci U S A 101, 13666-13671.

Gabor, C., Lymer, J., Phan, A., Choleris, E., 2015. Rapid effects of the G-protein coupled oestrogen receptor (GPER) on learning and dorsal hippocampus dendritic spines in female mice. Physiol Behav 149, 53-60.

Galef, B.G., 1989. An adaptationist perspective on social learning, social feeding and social foraging in norway rats, in: Dewsbury, D.A. (Ed.), Contemporary issues in comparative psychology. Sinauer Associates, Sunderland, MA.

Galef, B.G., Jr., 1988. Imitation in animals: history, definitions and interpretation of the data from the psychological laboratory, in: Zentall, T., Galef, B.G., Jr. (Eds.), Social learning: psychological and biological perspectives. Erlbaum, Hillsdale, NJ.

Galef, B.G., Wigmore, S.W., 1983. Transfer of information concerning distant foods: A laboratory investigation of the 'information-centre' hypothesis. Anim. Behav 31, 748-758.

Gheusi, G., Bluthe, R.M., Goodall, G., Dantzer, R., 1994. Social and individual recognition in rodents: Methodological aspects and neurobiological bases. Behavioural processes 33, 59-87.

Gilmore, R.F., Varnum, M.M., Forger, N.G., 2012. Effects of blocking developmental cell death on sexually dimorphic calbindin cell groups in the preoptic area and bed nucleus of the stria terminalis. Biol Sex Differ 3, 5.

Gladue, B.A., Clemens, L.G., 1978. Androgenic influences on feminine sexual behavior in male and female rats: defeminization blocked by prenatal antiandrogen treatment. Endocrinology 103, 17021709.

Gladue, B.A., Clemens, L.G., 1982. Development of feminine sexual behavior in the rat: androgenic and temporal influences. Physiol Behav 29, 263-267.

Gold, P.E., Countryman, R.A., Dukala, D., Chang, Q., 2011. Acetylcholine release in the hippocampus and prelimbic cortex during acquisition of a socially transmitted food preference. Neurobiology of learning and memory 96, 498-503.

Gorski, R.A., Gordon, J.H., Shryne, J.E., Southam, A.M., 1978. Evidence for a morphological sex difference within the medial preoptic area of the rat brain. Brain Res 148, 333-346.

Gorski, R.A., Harlan, R.E., Jacobson, C.D., Shryne, J.E., Southam, A.M., 1980. Evidence for the existence of a sexually dimorphic nucleus in the preoptic area of the rat. The Journal of comparative neurology 193, 529-539.

Greco, B., Allegretto, E.A., Tetel, M.J., Blaustein, J.D., 2001. Coexpression of ER beta with ER alpha and progestin receptor proteins in the female rat forebrain: effects of estradiol treatment. Endocrinology $142,5172-5181$.

Gresack, J.E., Schafe, G.E., Orr, P.T., Frick, K.M., 2009. Sex differences in contextual fear conditioning are associated with differential ventral hippocampal extracellular signal-regulated kinase activation.

Neuroscience 159, 451-467.

Guillamon, A., Segovia, S., del Abril, A., 1988. Early effects of gonadal steroids on the neuron number in the medial posterior region and the lateral division of the bed nucleus of the stria terminalis in the rat. Brain Res Dev Brain Res 44, 281-290.

Hadjimarkou, M.M., Vasudevan, N., 2018. GPER1/GPR30 in the brain: Crosstalk with classical estrogen receptors and implications for behavior. J Steroid Biochem Mol Biol 176, 57-64. 
Hart, D., Nilges, M., Pollard, K., Lynn, T., Patsos, O., Shiel, C., Clark, S.M., Vasudevan, N., 2014. Activation of the G-protein coupled receptor 30 (GPR30) has different effects on anxiety in male and female mice. Steroids 81, 49-56.

Hazell, G.G., Yao, S.T., Roper, J.A., Prossnitz, E.R., O'Carroll, A.M., Lolait, S.J., 2009. Localisation of GPR30, a novel $G$ protein-coupled oestrogen receptor, suggests multiple functions in rodent brain and peripheral tissues. J Endocrinol 202, 223-236.

Helena, C., Gustafsson, J.A., Korach, K., Pfaff, D., Anselmo-Franci, J.A., Ogawa, S., 2009. Effects of estrogen receptor alpha and beta gene deletion on estrogenic induction of progesterone receptors in the locus coeruleus in female mice. Endocrine 36, 169-177.

Heyes, C.M., 1994. Social learning in animals: categories and mechanisms. Biol Rev Camb Philos Soc 69, 207-231.

Hines, M., Allen, L.S., Gorski, R.A., 1992. Sex differences in subregions of the medial nucleus of the amygdala and the bed nucleus of the stria terminalis of the rat. Brain Res 579, 321-326.

Hisasue, S., Seney, M.L., Immerman, E., Forger, N.G., 2010. Control of cell number in the bed nucleus of the stria terminalis of mice: role of testosterone metabolites and estrogen receptor subtypes. J Sex Med 7, 1401-1409.

Hlinak, Z., 1993. Social recognition in ovariectomized and estradiol-treated female rats. Horm Behav 27, 159-166.

Huddleston, G.G., Paisley, J.C., Clancy, A.N., 2006. Effects of estrogen in the male rat medial amygdala: infusion of an aromatase inhibitor lowers mating and bovine serum albumin-conjugated estradiol implants do not promote mating. Neuroendocrinology 83, 106-116.

Imwalle, D.B., Scordalakes, E.M., Rissman, E.F., 2002. Estrogen receptor alpha influences socially motivated behaviors. Horm Behav 42, 484-491.

Ito, S., Murakami, S., Yamanouchi, K., Arai, Y., 1986. Perinatal androgen decreases the size of the sexually dimorphic medial preoptic nucleus in the rat. Proc Japan Acad Ser B62, 408.

Johnston, R.E., 2003. Chemical communication in rodents: from pheromones to individual recognition. J. Mammal 84, 1141-1162.

Juraska, J.M., Sisk, C.L., DonCarlos, L.L., 2013. Sexual differentiation of the adolescent rodent brain: hormonal influences and developmental mechanisms. Horm Behav 64, 203-210.

Kanaya, M., Morishita, M., Tsukahara, S., 2018. Temporal Expression Patterns of Genes Related to Sex Steroid Action in Sexually Dimorphic Nuclei During Puberty. Frontiers in endocrinology 9, 213.

Kanaya, M., Tsuda, M.C., Sagoshi, S., Nagata, K., Morimoto, C., Thu, C.K., Toda, K., Kato, S., Ogawa, S., Tsukahara, S., 2014. Regional difference in sex steroid action on formation of morphological sex differences in the anteroventral periventricular nucleus and principal nucleus of the bed nucleus of the stria terminalis. PLoS One 9, e112616.

Karlsson, S., Henningsson, S., Hovey, D., Zettergren, A., Jonsson, L., Cortes, D.S., Melke, J., Laukka, P., Fischer, H., Westberg, L., 2016. Social memory associated with estrogen receptor polymorphisms in women. Social cognitive and affective neuroscience 11, 877-883.

Kastenberger, I., Lutsch, C., Schwarzer, C., 2012. Activation of the G-protein-coupled receptor GPR30 induces anxiogenic effects in mice, similar to oestradiol. Psychopharmacology (Berl) 221, 527-535.

Kastenberger, I., Schwarzer, C., 2014. GPER1 (GPR30) knockout mice display reduced anxiety and altered stress response in a sex and paradigm dependent manner. Horm Behav 66, 628-636.

Kim, J., Szinte, J.S., Boulware, M.I., Frick, K.M., 2016. 17beta-Estradiol and Agonism of G-protein-Coupled Estrogen Receptor Enhance Hippocampal Memory via Different Cell-Signaling Mechanisms. J Neurosci 36, 3309-3321.

Koss, W.A., Gremminger, R.L., Philippi, S.M., Frick, K.M., 2017. Effects of dorsal hippocampal estradiol treatment and aromatase inhibition on memory consolidation in male mice. 
, Soc Neurosci Annual Meeting.

Kow, L.M., Pfaff, D.W., 2004. The membrane actions of estrogens can potentiate their lordosis behaviorfacilitating genomic actions. Proc Natl Acad Sci U S A 101, 12354-12357.

Kunn, T., Armstrong, S., Brar, R., Klemens, M., Choleris, E., 2017. Rapid estrogenic enhancements of learning and memory within the hippocampus of female mice: a role for membrane-bound receptors. , Society for Neuroscience Abstracts, p. 159.102.

Le Romancer, M., Treilleux, I., Bouchekioua-Bouzaghou, K., Sentis, S., Corbo, L., 2010. Methylation, a key step for nongenomic estrogen signaling in breast tumors. Steroids 75, 560-564.

Lebesgue, D., Reyna-Neyra, A., Huang, X., Etgen, A.M., 2009. GPR30 differentially regulates short latency responses of luteinising hormone and prolactin secretion to oestradiol. J Neuroendocrinol 21, 743-752. Lee, H., Kim, D.W., Remedios, R., Anthony, T.E., Chang, A., Madisen, L., Zeng, H., Anderson, D.J., 2014. Scalable control of mounting and attack by Esr1+ neurons in the ventromedial hypothalamus. Nature 509, 627-632.

Li, C., Brake, W.G., Romeo, R.D., Dunlop, J.C., Gordon, M., Buzescu, R., Magarinos, A.M., Allen, P.B., Greengard, P., Luine, V., McEwen, B.S., 2004. Estrogen alters hippocampal dendritic spine shape and enhances synaptic protein immunoreactivity and spatial memory in female mice. Proc Natl Acad Sci U S A 101, 2185-2190.

Lin, D., Boyle, M.P., Dollar, P., Lee, H., Lein, E.S., Perona, P., Anderson, D.J., 2011. Functional

identification of an aggression locus in the mouse hypothalamus. Nature 470, 221-226.

Long, N., Serey, C., Sinchak, K., 2014. 17beta-estradiol rapidly facilitates lordosis through G proteincoupled estrogen receptor 1 (GPER) via deactivation of medial preoptic nucleus mu-opioid receptors in estradiol primed female rats. Horm Behav 66, 663-666.

Lu, H., Ozawa, H., Nishi, M., Ito, T., Kawata, M., 2001. Serotonergic neurones in the dorsal raphe nucleus that project into the medial preoptic area contain oestrogen receptor beta. J Neuroendocrinol 13, 839845.

Lymer, J., Robinson, A., Winters, B.D., Choleris, E., 2017. Rapid effects of dorsal hippocampal G-protein coupled estrogen receptor on learning in female mice. Psychoneuroendocrinology 77, 131-140. Lymer, J.M., Sheppard, P.A.S., Kuun, T., Blackman, A., Jani, N., Mahbub, S., Choleris, E., 2018. Estrogens and their receptors in the medial amygdala rapidly facilitate social recognition in female mice.

Psychoneuroendocrinology 89, 30-38.

MacLusky, N.J., Lieberburg, I., McEwen, B.S., 1979. The development of estrogen receptor systems in the rat brain: perinatal development. Brain Res 178, 129-142.

MacLusky, N.J., Naftolin, F., 1981. Sexual differentiation of the central nervous system. Science 211, 1294-1302.

Mangelsdorf, D.J., Thummel, C., Beato, M., Herrlich, P., Schultz, G., Umeseno, K., Blumber, B., Kastner, P., Mark, M., Chambon, P., Evans, R.M., 1995. Overview: the nuclear receptor superfamily: the second decade. Cell 83, 835-840.

Matta, R., Ervin, S.J.K., Choleris, E., 2016a. The neurobiology of social learning, in: Olmstead, M.C. (Ed.), Animal Cognition: Principles, Evolution, and Development. Nova Science Publishers, New York.

Matta, R., Tiessen, A.N., Choleris, E., 2017. The Role of Dorsal Hippocampal Dopamine D1-Type Receptors in Social Learning, Social Interactions, and Food Intake in Male and Female Mice.

Neuropsychopharmacology 42, 2344-2353.

Matta, R., Underwood, E.A., Leach, Z.K., Vertes, A.C., Atabakhsh, V., Da Silva, M.B., Choleris, E., $2016 b$. Dopamine D2-type receptors in the dorsal hippocampus mediate social learning in female but not male mice, Society for Neuroscience Abstracts, p. 639.616.

Mazzucco, C.A., Walker, H.A., Pawluski, J.L., Lieblich, S.E., Galea, L.A., 2008. ERalpha, but not ERbeta, mediates the expression of sexual behavior in the female rat. Behav Brain Res 191, 111-117. 
McCarthy, M.M., Arnold, A.P., 2011. Reframing sexual differentiation of the brain. Nat Neurosci 14, 677683.

McEwen, B.S., Lieberburg, I., Chaptal, C., Krey, L.C., 1977. Aromatization: important for sexual differentiation of the neonatal rat brain. Horm Behav 9, 249-263.

Meng, Y., Zhang, Y., Tregoubov, V., Janus, C., Cruz, L., Jackson, M., Lu, W.Y., MacDonald, J.F., Wang, J.Y., Falls, D.L., Jia, Z., 2002. Abnormal spine morphology and enhanced LTP in LIMK-1 knockout mice. Neuron 35, 121-133.

Micevych, P.E., Dewing, P., 2011. Membrane-initiated estradiol signaling regulating sexual receptivity. Frontiers in endocrinology 2, 26.

Milner, T.A., Thompson, L.I., Wang, G., Kievits, J.A., Martin, E., Zhou, P., McEwen, B.S., Pfaff, D.W., Waters, E.M., 2010. Distribution of estrogen receptor beta containing cells in the brains of bacterial artificial chromosome transgenic mice. Brain Res 1351, 74-96.

Mitra, S.W., Hoskin, E., Yudkovitz, J., Pear, L., Wilkinson, H.A., Hayashi, S., Pfaff, D.W., Ogawa, S., Rohrer, S.P., Schaeffer, J.M., McEwen, B.S., Alves, S.E., 2003. Immunolocalization of estrogen receptor beta in the mouse brain: comparison with estrogen receptor alpha. Endocrinology 144, 2055-2067.

Mizukami, S., Nishizuka, M., Arai, Y., 1983. Sexual difference in nuclear volume and its ontogeny in the rat amygdala. Experimental neurology 79, 569-575.

Moe, Y., Kyi-Tha-Thu, C., Tanaka, T., Ito, H., Yahashi, S., Matsuda, K.I., Kawata, M., Katsuura, G., Iwashige, F., Sakata, I., Akune, A., Inui, A., Sakai, T., Ogawa, S., Tsukahara, S., 2016a. A Sexually

Dimorphic Area of the Dorsal Hypothalamus in Mice and Common Marmosets. Endocrinology 157, 48174828.

Moe, Y., Tanaka, T., Morishita, M., Ohata, R., Nakahara, C., Kawashima, T., Maekawa, F., Sakata, I., Sakai, T., Tsukahara, S., 2016b. A comparative study of sex difference in calbindin neurons among mice, musk shrews, and Japanese quails. Neurosci Lett 631, 63-69.

Morishita, M., Maejima, S., Tsukahara, S., 2017. Gonadal Hormone-Dependent Sexual Differentiation of a Female-Biased Sexually Dimorphic Cell Group in the Principal Nucleus of the Bed Nucleus of the Stria Terminalis in Mice. Endocrinology 158, 3512-3525.

Mosley, M., Weathington, J., Cortes, L.R., Bruggeman, E., Castillo-Ruiz, A., Xue, B., Forger, N.G., 2017. Neonatal Inhibition of DNA Methylation Alters Cell Phenotype in Sexually Dimorphic Regions of the Mouse Brain. Endocrinology 158, 1838-1848.

Murray, E.K., Hien, A., de Vries, G.J., Forger, N.G., 2009. Epigenetic control of sexual differentiation of the bed nucleus of the stria terminalis. Endocrinology 150, 4241-4247.

Musatov, S., Chen, W., Pfaff, D.W., Kaplitt, M.G., Ogawa, S., 2006. RNAi-mediated silencing of estrogen receptor \{alpha\} in the ventromedial nucleus of hypothalamus abolishes female sexual behaviors. Proc Natl Acad Sci U S A 103, 10456-10460.

Nakata, M., Sano, K., Musatov, S., Yamaguchi, N., Sakamoto, T., Ogawa, S., 2016. Effects of pre-pubertal or adult site-specific knockdown of estrogen receptor $\beta$ in the medial preoptic area and medial amygdala on social behaviors in male mice. eNeuro 3, 1-14.

Nelson, R.J., Trainor, B.C., 2007. Neural mechanisms of aggression. Nat Rev Neurosci 8, 536-546. Newman, S.W., 1999. The medial extended amygdala in male reproductive behavior. A node in the mammalian social behavior network. Ann N Y Acad Sci 877, 242-257.

Nilsson, S., Makela, S., Treuter, E., Tujague, M., Thomsen, J., Andersson, G., Enmark, E., Pettersson, K., Warner, M., Gustafsson, J., 2001. Mechanisms of estrogen action. Physiol Rev 81, 1535-1565.

Nishizuka, M., Arai, Y., 1981a. Organizational action of estrogen on synaptic pattern in the amygdala: implications for sexual differentiation of the brain. Brain Res 213, 422-426.

Nishizuka, M., Arai, Y., 1981b. Sexual dimorphism in synaptic organization in the amygdala and its dependence on neonatal hormone environment. Brain Res 212, 31-38. 
Nomura, M., Akama, K.T., Alves, S.E., Korach, K.S., Gustafsson, J.A., Pfaff, D.W., Ogawa, S., 2005. Differential distribution of estrogen receptor (ER)-alpha and ER-beta in the midbrain raphe nuclei and periaqueductal gray in male mouse: Predominant role of ER-beta in midbrain serotonergic systems. Neuroscience 130, 445-456.

Nomura, M., Andersson, S., Korach, K.S., Gustafsson, J.A., Pfaff, D.W., Ogawa, S., 2006. Estrogen receptor-beta gene disruption potentiates estrogen-inducible aggression but not sexual behaviour in male mice. Eur J Neurosci 23, 1860-1868.

Nomura, M., Durback, L., Chan, J., Gustafsson, J.-A., Smithies, O., Korach, K.S., Pfaff, D.W., Ogawa, S., 2002. Genotype/age interactions on aggressive behavior in gonadally intact estrogen receptor $b$ knockout (bERKO) male mice. Horm Behav 41, 288-296.

Nomura, M., Korach, K.S., Pfaff, D.W., Ogawa, S., 2003. Estrogen receptor beta (ERbeta) protein levels in neurons depend on estrogen receptor alpha (ERalpha) gene expression and on its ligand in a brain region-specific manner. Brain Res Mol Brain Res 110, 7-14.

Numan, M., Corodimas, K.P., Numan, M.J., Factor, E.M., Piers, W.D., 1988. Axon-sparing lesions of the preoptic region and substantia innominata disrupt maternal behavior in rats. Behavioral neuroscience 102, 381-396.

Ogawa, S., Chan, J., Chester, A.E., Gustafsson, J.A., Korach, K.S., Pfaff, D.W., 1999. Survival of reproductive behaviors in estrogen receptor beta gene-deficient (betaERKO) male and female mice. Proc Natl Acad Sci USA 96, 12887-12892.

Ogawa, S., Chester, A.E., Hewitt, S.C., Walker, V.R., Gustafsson, J.A., Smithies, O., Korach, K.S., Pfaff, D.W., 2000. Abolition of male sexual behaviors in mice lacking estrogen receptors alpha and beta (alpha beta ERKO). Proc Natl Acad Sci U S A 97, 14737-14741.

Ogawa, S., Eng, V., Taylor, J., Lubahn, D.B., Korach, K.S., Pfaff, D.W., 1998. Roles of estrogen receptoralpha gene expression in reproduction-related behaviors in female mice. Endocrinology 139, 5070-5081. Ogawa, S., Gordan, J., Taylor, J., Lubahn, D., Korach, K., Pfaff, D., 1996. Reproductive functions illustrating direct and indirect effects of genes on behavior. Hormones \& Behavior 30, 487-494. Ogawa, S., Lubahn, D.B., Korach, K.S., Pfaff, D.W., 1997. Behavioral effects of estrogen receptor gene disruption in male mice. Proc Natl Acad Sci USA 94, 1476-1481.

Ogawa, S., Washburn, T., Taylor, J., Lubahn, D., Korach, K., Pfaff, D., 1998b. Modifications of testosterone-dependent behaviors by estrogen receptor-alpha gene disruption in male mice. Endocrinology 139, 5058-5069.

Orikasa, C., Sakuma, Y., 2010. Estrogen configures sexual dimorphism in the preoptic area of C57BL/6J and ddN strains of mice. The Journal of comparative neurology 518, 3618-3629.

Oyola, M.G., Thompson, M.K., Handa, A.Z., Handa, R.J., 2017. Distribution and chemical composition of estrogen receptor beta neurons in the paraventricular nucleus of the female and male mouse hypothalamus. The Journal of comparative neurology 525, 3666-3682.

Paisley, J.C., Huddleston, G.G., Carruth, L.L., Petrulis, A., Grober, M.S., Clancy, A.N., 2012. Sexual responses of the male rat medial preoptic area and medial amygdala to estrogen I: site specific suppression of estrogen receptor alpha. Horm Behav 62, 50-57.

Paletta, P., Howard, S., Ali, K., Choleris, E., 2017. Social recognition is mediated by the interaction between the rapid effects of estrogens and oxytocin, Society for Neuroscience Abstracts, p. 159.113. Paletta, P., Sheppard, P.A.S., Matta, R., Ervin, K.S.J., Choleris, E., 2018. Rapid effects of estrogens on short-term memory: possible mechanisms. Horm Behav in press.

Paredes, R.G., Kica, E., Baum, M.J., 1994. Differential effects of the serotonin1A agonist, 8-OH-DPAT, on masculine and feminine sexual behavior of the ferret. Psychopharmacology (Berl) 114, 591-596.

Parsons, B., McEwen, B., Pfaff, D., 1982a. A discontinuous schedule of estradiol treatment is sufficient to activate progesterone-facilitated feminine sexual behavior and to increase cytosol receptors for progestins in the hypothalamus of the rat. Endocrinology 110, 613-619. 
Parsons, B., Rainbow, T., Pfaff, D., McEwen, B., 1982b. Hypothalamic protein synthesis essential for the activation of the lordosis reflex in the female rat. Endocrinology 110, 620-624.

Patchev, A.V., Gotz, F., Rohde, W., 2004. Differential role of estrogen receptor isoforms in sex-specific brain organization. FASEB J 18, 1568-1570.

Pfaff, D., 1999. Lordosis, in: Knobil, E., Neill, J. (Eds.), Encyclopedia of Reproduction. Academic Press, San Diego, pp. 1074-1075.

Pfaff, D., Waters, E., Khan, Q., Zhang, X., Numan, M., 2011. Minireview: estrogen receptor-initiated mechanisms causal to mammalian reproductive behaviors. Endocrinology 152, 1209-1217.

Pfaff, D.W., 1980. Estrogens and Brain Function: Neural Analysis of a Hormone Controlled Mammalian Reproductive Behavior. Springer Verlag, New York.

Pfaff, D.W., Sakuma, Y., 1979. Deficit in the lordosis reflex of female rats caused by lesions in the ventromedial nucleus of the hypothalamus. J Physiol (Lond) 288, 203-210.

Pfaus, J.G., Kippin, T.E., Coria-Avila, G., 2003. What can animal models tell us about human sexual response? Annu Rev Sex Res 14, 1-63.

Pfaus, J.G., Marcangione, C., Smith, W.J., Manitt, C., Abillamaa, H., 1996. Differential induction of Fos in the female rat brain following different amounts of vaginocervical stimulation: modulation by steroid hormones. Brain Res 741, 314-330.

Phan, A., Gabor, C.S., Favaro, K.J., Kaschack, S., Armstrong, J.N., MacLusky, N.J., Choleris, E., 2012. Low doses of 17beta-estradiol rapidly improve learning and increase hippocampal dendritic spines. Neuropsychopharmacology 37, 2299-2309.

Phan, A., Lancaster, K.E., Armstrong, J.N., MacLusky, N.J., Choleris, E., 2011. Rapid effects of estrogen receptor alpha and beta selective agonists on learning and dendritic spines in female mice.

Endocrinology 152, 1492-1502.

Phan, A., Suschkov, S., Molinaro, L., Reynolds, K., Lymer, J.M., Bailey, C.D., Kow, L.M., MacLusky, N.J., Pfaff, D.W., Choleris, E., 2015. Rapid increases in immature synapses parallel estrogen-induced hippocampal learning enhancements. Proc Natl Acad Sci U S A 112, 16018-16023.

Phoenix, C.H., Goy, R.W., Gerall, A.A., Young, W.C., 1959. Organizing action of prenatally administered testosterone proprionate on the tissues mediating mating behavior in the female guinea pig.

Endocrinology 65, 369-382.

Prossnitz, E.R., Barton, M., 2009. Signaling, physiological functions and clinical relevance of the G protein-coupled estrogen receptor GPER. Prostaglandins \& other lipid mediators 89, 89-97.

Prossnitz, E.R., Maggiolini, M., 2009. Mechanisms of estrogen signaling and gene expression via GPR30. Mol Cell Endocrinol 308, 32-38.

Qiu, J., Bosch, M.A., Tobias, S.C., Grandy, D.K., Scanlan, T.S., Ronnekleiv, O.K., Kelly, M.J., 2003. Rapid signaling of estrogen in hypothalamic neurons involves a novel G-protein-coupled estrogen receptor that activates protein kinase C. J Neurosci 23, 9529-9540.

Rainville, J., Pollard, K., Vasudevan, N., 2015. Membrane-initiated non-genomic signaling by estrogens in the hypothalamus: cross-talk with glucocorticoids with implications for behavior. Frontiers in endocrinology 6.

Rissman, E.F., Early, A.H., Taylor, J.A., Korach, K.S., Lubahn, D.B., 1997. Estrogen receptors are essential for female sexual receptivity. Endocrinology 138, 507-510.

Sa, S.I., Pereira, P.A., Malikov, V., Ferreira, I.M., Madeira, M.D., 2014. Role of plasma membrane estrogen receptors in mediating the estrogen induction of progesterone receptors in hypothalamic ventromedial neurons. The Journal of comparative neurology 522, 298-307.

Sagoshi, S., Maejima, S., Morishita, M., Otubo, A., Takanami, K., Sakamoto, T., Sakamoto, H., Tsukahara, S., Ogawa, S., 2018. Detection and characterization of estrogen receptor beta expression in the brain of newly developed transgenic mice. Submitted for publication. 
Sanchez-Andrade, G., Kendrick, K.M., 2011. Roles of alpha- and beta-estrogen receptors in mouse social recognition memory: effects of gender and the estrous cycle. Horm Behav 59, 114-122.

Sano, K., Morimoto, C., Nataka, M., Musatov, S., Tsuda, M.C., Yamaguchi, N., Sakamoto, T., Ogawa, S., 2018. The Role of Estrogen Receptor beta in the Dorsal Raphe Nucleus on the Expression of Female Sexual Behavior in C57BL/6J Mice. Frontiers in endocrinology 9, 243.

Sano, K., Nakata, M., Musatov, S., Morishita, M., Sakamoto, T., Tsukahara, S., Ogawa, S., 2016. Pubertal activation of estrogen receptor alpha in the medial amygdala is essential for the full expression of male social behavior in mice. Proc Natl Acad Sci U S A 113, 7632-7637.

Sano, K., Tsuda, M.C., Musatov, S., Sakamoto, T., Ogawa, S., 2013a. Differential effects of site-specific knockdown of estrogen receptor alpha in the medial amygdala, medial pre-optic area, and ventromedial nucleus of the hypothalamus on sexual and aggressive behavior of male mice. Eur J Neurosci 37, 13081319.

Sano, K., Vasudevan, N., Nagata, K., Nakata, M., Uchimura, T., Xiao, K., Tsuda, M.C., Ogawa, S., 2013 b. Loss of neuronal ER $\alpha$ abolishes sexual and aggressive behaviors in male mice. Tsukuba Psychol Res 45, 19.

Schulz, K.M., Zehr, J.L., Salas-Ramirez, K.Y., Sisk, C.L., 2009. Testosterone programs adult social behavior before and during, but not after, adolescence. Endocrinology 150, 3690-3698.

Sheppard, P.A.S., Lumsden, A., Ashley, J.S., Choleris, E., 2017a. The effects of MEK/ERK inhibition on rapid estrogen receptor alpha and G-protein coupled estrogen receptor facilitated social recognition., Organization for the Study of Sex Differences, p. 109.

Sheppard, P.A.S., Lumsden, A., Watson, I., Sellers, K.J., Srivastava, D.P., Choleris, E., 2017b. The effects of $\mathrm{PI} 3 \mathrm{~K}$ inhibition on the rapid facilitation of social recognition by estrogens and estrogen receptor agonists in the dorsal hippocampi of female mice., Society of Neuroscience Abstracts, Washington, DC, p.

159.103.

Shughrue, P.J., Lane, M.V., Merchenthaler, I., 1997. Comparative distribution of estrogen receptor-alpha and -beta mRNA in the rat central nervous system. The Journal of comparative neurology 388, 507-525.

Shughrue, P.J., Scrimo, P.J., Merchenthaler, I., 1998. Evidence for the colocalization of estrogen receptor-beta mRNA and estrogen receptor-alpha immunoreactivity in neurons of the rat forebrain. Endocrinology 139, 5267-5270.

Sickel, M.J., McCarthy, M.M., 2000. Calbindin-D28k immunoreactivity is a marker for a subdivision of the sexually dimorphic nucleus of the preoptic area of the rat: developmental profile and gonadal steroid modulation. J Neuroendocrinol 12, 397-402.

Simerly, R.B., Zee, M.C., Pendleton, J.W., Lubahn, D.B., Korach, K.S., 1997. Estrogen receptor-dependent sexual differentiation of dopaminergic neurons in the preoptic region of the mouse. Proc Natl Acad Sci $U$ S A 94, 14077-14082.

Snyder, M.A., Smejkalova, T., Forlano, P.M., Woolley, C.S., 2010. Multiple ERbeta antisera label in ERbeta knockout and null mouse tissues. Journal of neuroscience methods 188, 226-234.

Spiteri, T., Agmo, A., 2009. Ovarian hormones modulate social recognition in female rats. Physiol Behav 98, 247-250.

Spiteri, T., Musatov, S., Ogawa, S., Ribeiro, A., Pfaff, D.W., Agmo, A., 2010. The role of the estrogen receptor alpha in the medial amygdala and ventromedial nucleus of the hypothalamus in social recognition, anxiety and aggression. Behav Brain Res 210, 211-220.

Srivastava, D.P., Woolfrey, K.M., Jones, K.A., Shum, C.Y., Lash, L.L., Swanson, G.T., Penzes, P., 2008. Rapid enhancement of two-step wiring plasticity by estrogen and NMDA receptor activity. Proc Natl Acad Sci U S A 105, 14650-14655.

Steel, E., 1983. Female sexual behaviour: roles of gonadal hormones in the Syrian hamster. Physiol Behav 31, 453-459. 
Sumida, H., Nishizuka, M., Kano, Y., Arai, Y., 1993. Sex differences in the anteroventral periventricular nucleus of the preoptic area and in the related effects of androgen in prenatal rats. Neurosci Lett 151, 41-44.

Tang, A.C., Nakazawa, M., Romeo, R.D., Reeb, B.C., Sisti, H., McEwen, B.S., 2005. Effects of long-term estrogen replacement on social investigation and social memory in ovariectomized C57BL/ 6 mice. Horm Behav 47, 350-357.

Temple, J.L., Wray, S., 2005. Bovine serum albumin-estrogen compounds differentially alter gonadotropin-releasing hormone-1 neuronal activity. Endocrinology 146, 558-563.

Thomas, P., Pang, Y., Filardo, E.J., Dong, J., 2005. Identity of an estrogen membrane receptor coupled to a G protein in human breast cancer cells. Endocrinology 146, 624-632.

Tsuda, M.C., Yamaguchi, N., Nakata, M., Ogawa, S., 2014. Modification of female and male social behaviors in estrogen receptor beta knockout mice by neonatal maternal separation. Frontiers in neuroscience 8, 274.

Tsuda, M.C., Yamaguchi, N., Ogawa, S., 2011. Early life stress disrupts peripubertal development of aggression in male mice. Neuroreport 22, 259-263.

Tsukahara, S., 2009. Sex differences and the roles of sex steroids in apoptosis of sexually dimorphic nuclei of the preoptic area in postnatal rats. J Neuroendocrinol 21, 370-376.

Tsukahara, S., Tsuda, M.C., Kurihara, R., Kato, Y., Kuroda, Y., Nakata, M., Xiao, K., Nagata, K., Toda, K., Ogawa, S., 2011. Effects of aromatase or estrogen receptor gene deletion on masculinization of the principal nucleus of the bed nucleus of the stria terminalis of mice. Neuroendocrinology 94, 137-147. Tsuneoka, Y., Maruyama, T., Yoshida, S., Nishimori, K., Kato, T., Numan, M., Kuroda, K.O., 2013. Functional, anatomical, and neurochemical differentiation of medial preoptic area subregions in relation to maternal behavior in the mouse. The Journal of comparative neurology 521, 1633-1663.

Vasudevan, N., Kow, L.M., Pfaff, D., 2005. Integration of steroid hormone initiated membrane action to genomic function in the brain. Steroids 70, 388-396.

Vasudevan, N., Kow, L.M., Pfaff, D.W., 2001. Early membrane estrogenic effects required for full expression of slower genomic actions in a nerve cell line. Proc Natl Acad Sci U S A. 98, 12267-12271. Vasudevan, N., Pfaff, D.W., 2007. Membrane-initiated actions of estrogens in neuroendocrinology: emerging principles. Endocr Rev 28, 1-19.

Wang, H., Ward, A.R., Morris, J.F., 1995. Oestradiol acutely stimulates exocytosis of oxytocin and vasopressin from dendrites and somata of hypothalamic magnocellular neurons. Neuroscience 68,1179 1188.

Wersinger, S.R., Sannen, K., Villalba, C., Lubahn, D.B., Rissman, E.F., De Vries, G.J., 1997. Masculine sexual behavior is disrupted in male and female mice lacking a functional estrogen receptor alpha gene. Horm Behav 32, 176-183.

Whalen, R.E., Nadler, R.D., 1963. Suppression of the development of female mating behavior by estrogen administered in infancy. Science 141, 273-274.

Winocur, G., 1990. Anterograde and retrograde amnesia in rats with dorsal hippocampal or dorsomedial thalamic lesions. Behav Brain Res 38, 145-154.

Wittmann, W., McLennan, I.S., 2013a. Anti-Mullerian hormone may regulate the number of calbindinpositive neurons in the sexually dimorphic nucleus of the preoptic area of male mice. Biol Sex Differ 4, 18.

Wittmann, W., McLennan, I.S., 2013b. The bed nucleus of the stria terminalis has developmental and adult forms in mice, with the male bias in the developmental form being dependent on testicular AMH. Horm Behav 64, 605-610.

Wood, J.R., Likhite, V.S., Loven, M.A., Nardulli, A.M., 2001. Allosteric modulation of estrogen receptor conformation by different estrogen response elements. Mol Endocrinol 15, 1114-1126. 
Zheng, D.J., Foley, L., Rehman, A., Ophir, A.G., 2013. Social recognition is context dependent in single male prairie voles. Anim Behav 86.

Zuloaga, D.G., Zuloaga, K.L., Hinds, L.R., Carbone, D.L., Handa, R.J., 2014. Estrogen receptor beta expression in the mouse forebrain: age and sex differences. The Journal of comparative neurology 522 , 358-371. 


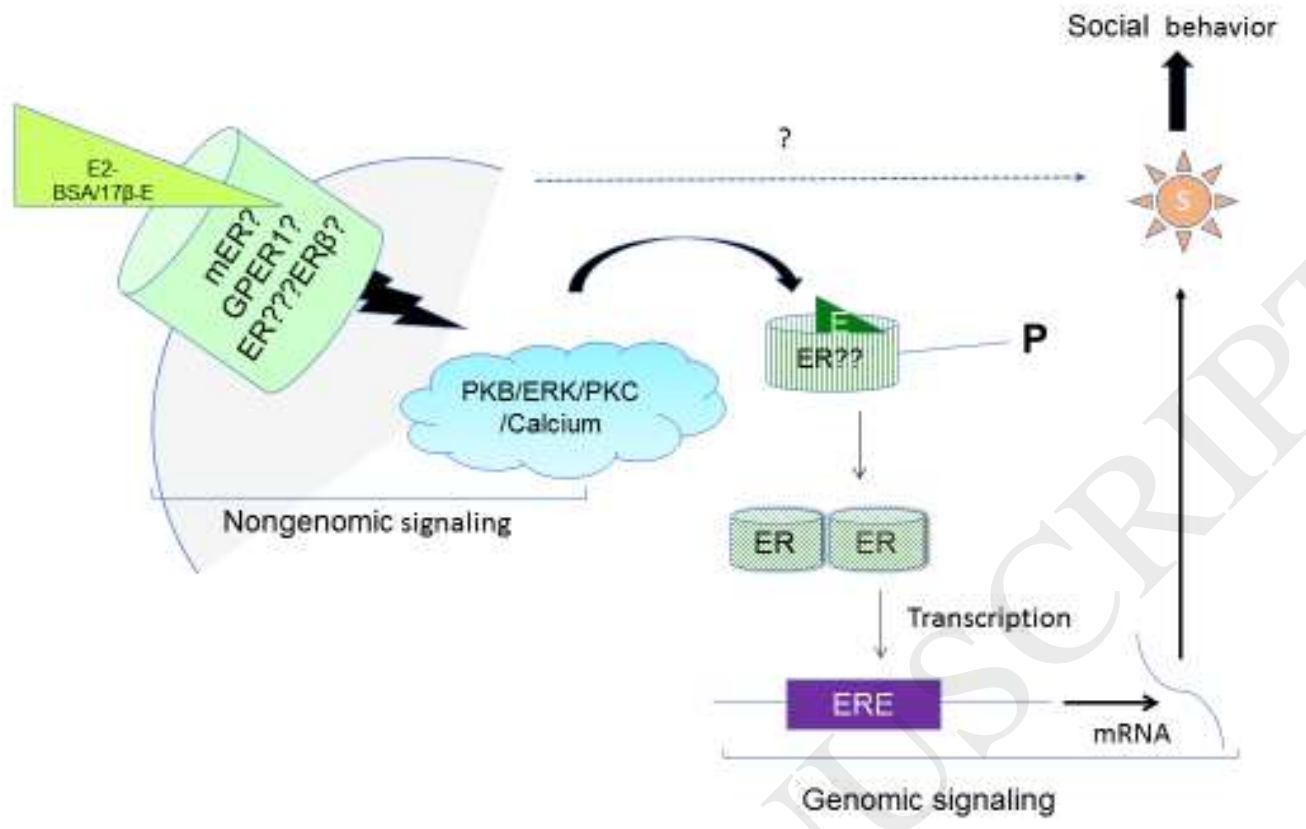




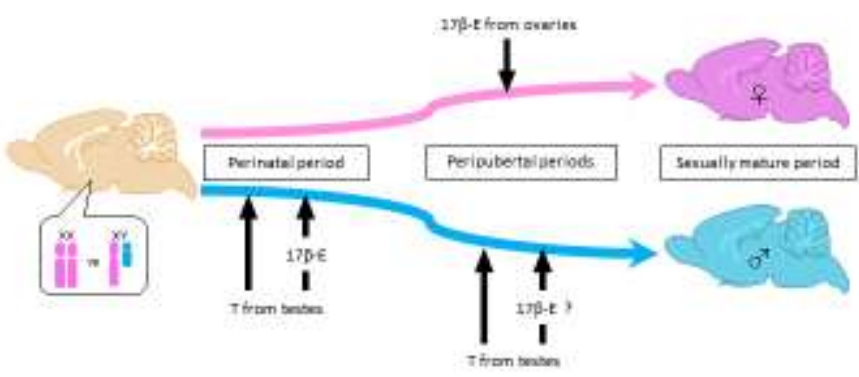

Fig. 2 


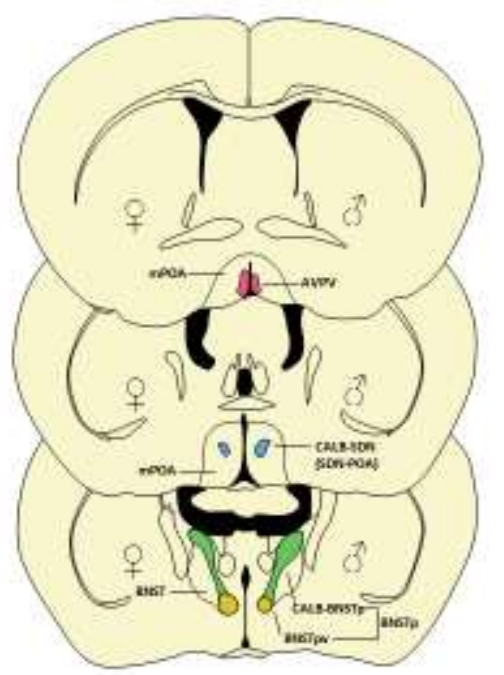

Fig. 3 